\title{
Effects of Australian Economic Activities on Waste Generation and Treatment
}

\author{
He He ${ }^{1, *}$, Christian John Reynolds ${ }^{2, *}$ (D), Julia Piantadosi ${ }^{1}$ and John Boland ${ }^{1}$ \\ 1 Centre for Industrial and Applied Mathematics, Mawson Lakes Campus, University of South Australia, \\ Mawson Lakes, SA 5095, Australia; juliapiantadosi@bigpond.com (J.P.); John.Boland@unisa.edu.au (J.B.) \\ 2 Department of Geography, Faculty of Social Sciences, The University of Sheffield, Sheffield S10 2TN, UK \\ * Correspondence: he.he@mymail.unisa.edu.au (H.H.); c.reynolds@sheffield.ac.uk (C.J.R.)
}

Received: 5 June 2017; Accepted: 26 July 2017; Published: 31 July 2017

\begin{abstract}
Understanding the relationships between the Australian economic system and waste generation from intermediate sectors and households is a prerequisite for planning and implementing waste management strategies at a national scale. Data of waste generation accounts link to those of national economic accounts. However, in Australia, some years' data are absent and so these links cannot be made. To rectify this data gap, this paper interpolates and extrapolates the Australian input-output table (IOT) of 2010-2011. Waste input-output (WIO) analysis is then used to assess the effects of the Australian economy on waste generation and treatment between 2009-2010 and 2010-2011. Analysis indicated that the result of interpolation was more reasonable than that of extrapolation, and the interpolation of the Australian IOT of 2010-2011 can be applicable. This comparative analysis of the time series data in WIO model has identified that: (1) per million \$AUD of output of the Construction sector generated the most amount of direct and total waste during the period; (2) the relationships between the development of Australian economy and waste generation illustrate that the Australian economy is currently a traditional linear economy; (3) the effectiveness of waste-related policies are shown by the growth of the sums of direct and total effects of intermediate sectors on the Recovery sector; and (4) the amount of waste generated by households increased sharply over the two years. The physical flows of waste footprint show details of waste generation and treatment in the Australian economic system. The information provided in this paper is beneficial to formulate tailor-made policies for waste management in Australia.
\end{abstract}

Keywords: input-output analysis; waste input output; waste footprint

\section{Introduction}

Waste is an inevitable by-product of economic activities. The amount of waste generated is directly relevant to the economic situation of countries [1]. The quantity of waste grows with the increase of population and gross domestic product (GDP). This occurs in developing and developed countries [1-3]. The Australian Bureau of Statistics has estimated that waste generation in Australia has increased by 145\% from 1997 to 2012 with the Gross Value Added rising by $64 \%$ and the population increasing by $22 \%$ [4]. The Australian government has published a series of policies for waste management, such as the National Waste Policy agreed upon in November 2009 [5] and the Environment Protection Regulations 2009 published on 1 July 2010 [6]. The former aims at producing less waste for disposal and treating waste as a resource from 2010 to 2020. The objectives of the latter include prevention, minimisation or elimination of harm for the environment by penalties for late lodgement and waste levies. The focus on waste generation and treatment is significant-to analyse how economic activities and environmental policies affect waste trends. 
Since the late 1960s, the relationships between economic activities and waste generation have been analysed using the input-output (IO) model [7]. As an extension of the IO model, Leontief's environmental input-output (EIO) model has proposed to take account of pollution generation and abatement by adding data of the anti-pollution sector with the related data on pollutants [8].

Waste input-output (WIO) analysis based on the EIO model has been developed to solve the issue of linking waste types with treatment methods because different types of waste treatment methods can dispose of several types of waste [9]. Both the EIO and WIO models have been applied to analyse the relationships of waste generation and intermediate sectors. Joosten, Hekkert, and Worrell (2000) [10] used national supply and use tables to explore the relationships between plastic products and intermediate sectors in The Netherlands in 1990. The WIO model was applied to analyse the relationships between Japanese economic activities and environmental load under five scenarios in 1995 [11].

The relationships between Australian economic activities and waste generation in 2008-2009 were discussed using waste supply-use tables (WSUTs) (an extension of WIO). These show how waste generation is affected by the intermediate sectors and waste treatment sectors [12] Based on the WSUTs, a multi-regional waste supply-use (MRWSU) has been developed to analyse the indicators of waste generation, such as waste footprint (where and how many tonnes of all types of waste are generated and treated in the economic system) and sectoral waste production intensities [13].

Research on the combination of waste generation accounts and national economic accounts provides effective information for waste-economic analysis and policy making [13]). The limitation for the combination was that there was not a unifying framework for waste generation accounts and national economic accounts before 2014 [14]. Although C. Reynolds, Geschke, Piantadosi, and Boland (2015) [15] have published a method to tackle the limitation, the accuracy of the method should be verified by other waste estimation approaches. The unifying framework for waste generation accounts and national economic accounts has been created in the System of Environmental-Economic Accounting (SEEA), adopted by the United Nations Statistical Commission in 2012 [14] and the Australian Bureau of Statistics in 2016 [16]. The ABS waste account has shown a series of experimental tables showing the physical supply (generation) of waste by intermediate sectors and households and the physical use (management of) waste via landfill, recovery or export [16]. This can obviously enhance the accuracy of analysing the relationships between Australian waste generation accounts and Australian national economic accounts in a single year.

In addition, waste generation and treatment are linked to economic activity and environmental policies, and researchers need to recognize and identify the change of effects from economic activities and environmental policies on waste generation and treatment. Especially, more knowledge of comparative analysis based on two-year WIO models is needed. However, there is a limited time series of Australian waste data available, with the data available having many different grouping and accounting methods [15]. Only the waste data in the years 2009-2010 and 2010-2011 are appearing in a consistent format $[4,17]$. Moreover, while there is a 2009-2010 IOT, there is not a 2010-2011 IOT with which to harmonise the Australian waste data.

In this paper, we obtain two aggregated Australian IOTs for the 2010-2011 time period by interpolating and extrapolating from other aggregated Australian IOTs. The extrapolation uses base IOTs from 2006-2007, 2007-2008, 2008-2009, and 2009-2010 to create a 2010-2011 IOT while the interpolation uses the base IOTs from 2006 to 2009 and also the 2012-2013 IOT [18-22]. A comparative analysis of the forecasting accuracy between the interpolation and extrapolation shows that the result of interpolation is more reasonable.

We then apply Nakamura and Kondo's WIO to build the Australian WIO in 2009-2010 and the interpolated version of Australian WIO in 2010-2011 to analyse how the amount of waste generation is influenced by the change of Australian economic activities. This is the first version of the time-series Australian WIO tables based on the Australian Bureau of Statistics' IO tables and waste accounts. 
Australian waste footprints in 2009-2010 and 2010-2011 are presented based on the time-series Australian WIO tables to illustrate where and how many tonnes of all types of waste are generated during the production of goods and services and treated by waste treatment methods. The time-series of WIO tables can be constructed in other countries and regions to offer information between economic activities and waste management for governments to design tailored environmental policies.

The aggregated Australian IOTs and the whole process of interpolating and extrapolating the Australian IOTs in 2010-2011 are shown from Table S1 to Table S5 and Table S6 to Table S22, available in the supplementary file.

The terms and their corresponding abbreviations are defined in Table 1.

Table 1. The sector terms and their corresponding abbreviations in the study.

\begin{tabular}{cc}
\hline Terms & Abbreviations \\
\hline Agriculture, forestry, and fishing & AG \\
Mining & MI \\
Manufacturing & MA \\
Electricity, gas, and water & EGW \\
Waste management services & WMS \\
Construction & CO \\
Public administration & PA \\
All other industry & AOI \\
Paper and cardboard & Pap \& C \\
Glass & GL \\
Plastics & PL \\
Metals & ME \\
Organics & Org \\
Masonry & Mas \\
Electrical and electronic waste & EE \\
Solid hazardous waste & SH \\
Leather and textiles & L \& T \\
Tyres and other rubber & T \& OR \\
Timber and wood products & T \& Wood \\
Inseparable/unknown waste & I/U \\
Australian Bureau of Statistics & ABS \\
\hline
\end{tabular}

\section{Methodology}

The methodology was conducted in two steps: (1) the formation of Australian WIO model; and (2) the interpolation and extrapolation of Australian aggregation IOTs in 2010-2011.

\subsection{The Framework and Notation of the WIO Model}

An aggregation WIO framework is introduced in Table 2 that contains intermediate sectors with seven intermediate sectors, two treatment sectors, final demand referring to the households, and total output. 
Table 2. An aggregation waste input-output (WIO) framework based on various sectors of the Australian economy.

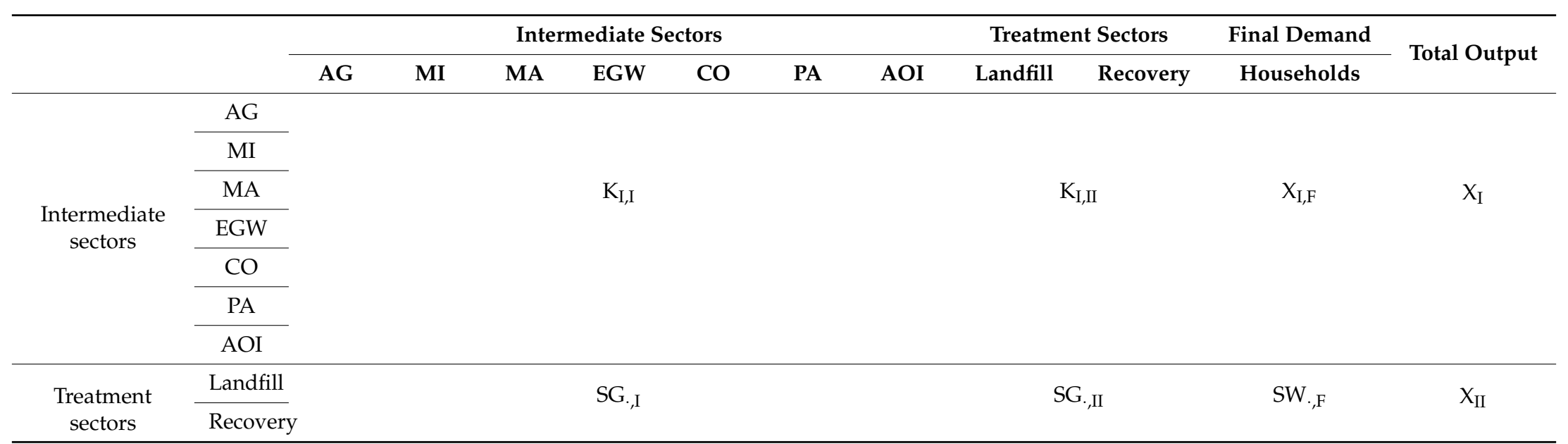

Note: Agriculture, forestry, and fishing = AG; Mining = MI; Manufacturing = MA; Electricity, gas, and water = EGW; Waste management services = WMS; Construction = CO; Public administration $=$ PA; All other industry $=$ AOI. $K_{\mathrm{II}} \in R^{N^{\mathrm{I}} \times N^{\mathrm{I}}}$ represents intermediate sectors' matrix for $N^{\mathrm{I}}$ goods and service-producing sectors, $\mathrm{K}_{\mathrm{IJ}} \in R^{N^{\mathrm{I}} \times N^{\mathrm{II}}}$ means the monetary inputs from per intermediate industry into $N^{\mathrm{II}}$ waste treatment sectors, $\mathrm{S}$ is an $N^{\mathrm{II}} \times N^{w}$ nonnegative matrix for $N^{w}$ waste types, $\mathrm{G}_{\text {, I }}$ is defined as an $N^{w} \times N^{\mathrm{I}}$ matrix for the category of waste generated by intermediate sector, $\mathrm{G}_{\text {, II }}$ represents an $N^{w} \times N^{\mathrm{II}}$ matrix that the waste is generated by $N^{\mathrm{II}}$ waste treatment sectors. A final demand matrix for $N^{\mathrm{I}}$ goods and service-producing sectors is defined as $\mathrm{X}_{\mathrm{I}, \mathrm{F}}$ for $N^{\mathrm{F}}$ sectors, and $\mathrm{W}_{,, \mathrm{F}}$ is the waste generated by final demand. $\mathrm{x}_{\mathrm{I}} \in R^{N^{\mathrm{I}} \times 1}$ refers to a gross output vector for $N^{\mathrm{I}}$ goods and service-producing sectors, and $x_{\mathrm{II}} \in R^{N^{\mathrm{II}} \times 1}$ presents the total amount of waste to be treated by $N^{\mathrm{II}}$ waste treatment sectors. 
We will use the notation described in Nakamura and Kondo (2002a) [9]. The WIO model in balanced form is written as

$$
\left(\begin{array}{cc}
\mathrm{K}_{\mathrm{I}, \mathrm{I}} & \mathrm{K}_{\mathrm{I}, \mathrm{II}} \\
\mathrm{SG}_{\cdot, \mathrm{I}} & \mathrm{SG}_{\cdot, \mathrm{II}}
\end{array}\right)\left(\begin{array}{c}
\mathrm{x}_{\mathrm{I}} \\
\mathrm{X}_{\mathrm{II}}
\end{array}\right)+\left(\begin{array}{c}
\mathrm{X}_{\mathrm{I}, \mathrm{F}} \\
\mathrm{SW}_{\cdot, \mathrm{F}}
\end{array}\right)=\left(\begin{array}{c}
\mathrm{x}_{\mathrm{I}} \\
\mathrm{x}_{\mathrm{II}}
\end{array}\right)
$$

where $\mathrm{K}_{\mathrm{I}, \mathrm{I}} \in R^{N^{\mathrm{I}} \times N^{\mathrm{I}}}$ represents intermediate sectors' matrix for $N^{\mathrm{I}}$ goods and service-producing

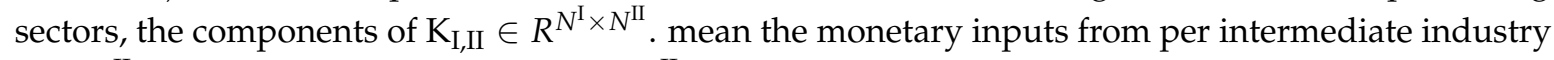
into $N^{\mathrm{II}}$. waste treatment sectors, $\mathrm{S}$ is an $N^{\mathrm{II}} \times N^{w}$ nonnegative matrix for $N^{w}$ waste types, and the $s_{i j}$ in the matrix represents the proportion of waste $j$ treated by waste treatment method $i$, G., is defined as an $N^{w} \times N^{\mathrm{I}}$ matrix for the category of waste generated by intermediate sector, G.,II represents an $N^{w} \times N^{\mathrm{II}}$ matrix that the waste is generated by $N^{\mathrm{II}}$ waste treatment sectors. A final demand matrix for $N^{\mathrm{I}}$ goods and service-producing sectors is defined as $\mathrm{X}_{\mathrm{I}, \mathrm{F}}$ or $N^{\mathrm{F}}$ sectors, and $\mathrm{W}_{., \mathrm{F}}$ is the waste generated by final demand. $\mathrm{x}_{\mathrm{I}} \in R^{N^{\mathrm{I}} \times 1}$ refers to a gross output vector for $N^{\mathrm{I}}$ goods and service-producing sectors, and $\mathrm{x}_{\mathrm{II}} \in R^{N^{\mathrm{II}} \times 1}$ presents the total amount of waste to be treated by $N^{\mathrm{II}}$ waste treatment sectors.

The coefficient matrix of WIO model can be expressed

$$
\left(\begin{array}{cc}
\mathrm{A}_{\mathrm{I}, \mathrm{I}} & \mathrm{A}_{\mathrm{I}, \mathrm{II}} \\
\mathrm{B}_{\mathrm{I}, \mathrm{I}} & \mathrm{B}_{\mathrm{II}, \mathrm{II}}
\end{array}\right)\left(\begin{array}{c}
\mathrm{x}_{\mathrm{I}} \\
\mathrm{X}_{\mathrm{II}}
\end{array}\right)+\left(\begin{array}{c}
\mathrm{X}_{\mathrm{I}, \mathrm{F}} \\
\mathrm{SW}, \mathrm{F}
\end{array}\right)=\left(\begin{array}{c}
\mathrm{x}_{\mathrm{I}} \\
\mathrm{x}_{\mathrm{II}}
\end{array}\right)
$$

where we define input coefficients matrices $A_{I, I}=K_{I, I} \hat{x}_{I}^{-1}$ (million \$AUD/million \$AUD), $\mathrm{A}_{\mathrm{I}, \mathrm{II}}=\mathrm{K}_{\mathrm{I}, \mathrm{II}} \hat{x}_{\mathrm{II}}^{-1}$ (million \$AUD/t), $\mathrm{B}_{\mathrm{I}, \mathrm{I}}=\mathrm{SG}$, , $\hat{x}_{\mathrm{I}}^{-1}$ (million $\left.\$ A U D / \$\right)$, and $\mathrm{B}_{\mathrm{II}, \mathrm{II}}=\mathrm{SG}$, II $\hat{x}_{\mathrm{II}}^{-1}(\mathrm{t} / \mathrm{t}$ ), where the "hat" over a vector $x$ denotes a diagonal matrix with the elements of the vector along the main diagonal. For instance, if $\mathrm{X}=\left[\begin{array}{l}x_{1} \\ x_{2} \\ x_{3}\end{array}\right]$ then $\hat{x}=\begin{array}{ccc}\mathrm{x}_{1} & 0 & 0 \\ 0 & \mathrm{x}_{2} & 0 \\ 0 & 0 & \mathrm{x}_{3}\end{array}$.

The solution of Equation (2) is given by

$$
\left(\begin{array}{c}
\mathrm{x}_{\mathrm{I}} \\
\mathrm{x}_{\mathrm{II}}
\end{array}\right)=\left(\mathrm{I}-\left(\begin{array}{cc}
\mathrm{A}_{\mathrm{I}, \mathrm{I}} & \mathrm{A}_{\mathrm{I}, \mathrm{II}} \\
\mathrm{B}_{\mathrm{I}, \mathrm{I}} & \mathrm{B}_{\mathrm{II}, \mathrm{II}}
\end{array}\right)\right)^{-1}\left(\begin{array}{c}
\mathrm{X}_{\mathrm{I}, \mathrm{F}} \\
\mathrm{SW} \cdot, \mathrm{F}
\end{array}\right)
$$

\subsection{Data Aggregation, Interpolation and Extrapolation}

The Australian IOTs are published by the ABS in million AUD dollars. The Australian IOTs of 2006-2007, 2007-2008, 2008-2009, 2009-2010 and 2012-2013 were chosen for the estimation of the Australian IOT of 2010-2011 because Australian and New Zealand Standard Industrial Classification has been published since 2006, and the pre-2006 classification standard of sectors is different [18-23]. To be specific, Employment, Travel Agency and Other Administrative Services was added to the list of classification of the Australian IOT, and the Education and Training sector was divided into Primary and Secondary Education Services (include Pre-Schools and Special Schools), Technical, Vocational and Tertiary Education Services (include undergraduate and postgraduate), and Arts, Sports, Adult and Other Education Services after 2006 (includes community education) [23]. The column of the Other final demand is composed of the government consumption, gross fixed capital formation, changes in inventories and exports.

Australian waste accounts include 8 intermediate sectors, the households and 12 waste categories in 2009-2010 and 2010-2011 [16]. The Australian IOTs analysed in this paper only consider domestically generated and disposed waste, but not imported and exported waste.

The definition of the All other industries sector shown in the ABS database is different in the two files from the Australian and New Zealand Standard Industrial Classification and the Australian Environmental-Economic Accounts [16,23]. For example, the All other industries sector in the Australian Environmental-Economic Accounts include the Electricity, gas and water supply industries, 
and All other service industries, while that in the Australian and New Zealand Standard Industrial Classification includes Wholesale, retail, transport, postal and warehousing, and All other service industries (except Electricity, gas and water supply industries). All other industries in the Australian Environmental-Economic Accounts are applied in the calculation of the total amount of inputs from Waste collection, treatment and disposal services into intermediate sectors while that in the Australian and New Zealand Standard Industrial Classification is considered as an intermediate sector in this research.

The Australian IOT in 2010-2011 is missing due to a lack of funding in 2010-2011 while the Australian IOTs tables of the previous years and 2012-2013 have been published. Therefore, the Australian aggregation IOT in 2010-2011 can be formed via interpolation and extrapolation. The section below explains the methodology used to interpolate and extrapolate the Australian aggregation IOT of 2010-2011.

The progress of interpolating and extrapolating Australian IOTs of 2010-2011 is carried out in three steps. First, 111 intermediate sectors from the Australian IOTs of 2006-2007, 2007-2008, and 2008-2009 were aggregated into 8 intermediate sectors, and 114 intermediate sectors from the Australian IOTs of 2009-2010 and 2012-2013 were aggregated into 8 intermediate sectors according to the Australian and New Zealand Standard Industrial Classification. The column of the Final demand only refers to Final Consumption Expenditure, Gross Fixed Capital Formation, Changes in inventories, and Exports. Second, the amount of inputs in individual cells from the Waste management services sector to intermediate sectors and that from the Construction sector to the Waste management services sector in 2010-2011 can be accessed in ABS database [16]. Finally, the amount of inputs in individual cells from intermediate sectors (excluding the Construction sector) to intermediate sectors in 2010-2011 can be estimated by using linear and quadratic polynomials.

The data is interpolated by applying the linear regression equation according to:

$$
\mathrm{Y}=\mathrm{AX}+\mathrm{B} \text {. }
$$

Or the data is interpolated by applying the quadratic polynomial equation according to:

$$
\mathrm{Y}=\mathrm{a} \mathrm{X}^{2}+\mathrm{bX}+\mathrm{c}
$$

Here, Y represents the amount of inputs in individual cells from rows of intermediate sectors into columns of intermediate sectors and $\mathrm{X}$ indicates the year of the IO data. A and B are constant in Equation (4) with considering 2006-2007 as Year 1 and 2012-2013 as Year 7 and a, b, and c are constant in Equation (5) with considering 2009-2010 as Year 4 and 2012-2013 as Year 7.

The extrapolation of Australian IOTs of 2010-2011 is also calculated by the same procedure of interpolation based on the same time-series Australian IOTs, with the year of 2012-2013 excluded.

The aggregated Australian IOTs of 2009-2010 and 2010-2011 are used to provide the WIO block $\mathrm{K}_{\mathrm{I}, \mathrm{I}}, N^{\mathrm{I}}=7$ intermediate sectors, the total output of goods and services $\mathrm{x}_{\mathrm{I}}$, and $\mathrm{X}_{\mathrm{I}, \mathrm{F}}$ represents the Final demand. In order to estimate the effect of different waste treatment methods on different types of waste, both the columns of the Landfill sector and the Recovery sector disaggregated according to the data of the column of the Waste management services sector represent $K_{I, I I}$, yielding $N^{I I}=2$ eparate treatment sectors. The method of disaggregation uses each type of waste treatment method's share in the waste management services sectors as weight [17]. The data from the ABS database [16] (provide the WIO block $\mathrm{G}_{\text {,I }}$ and $\mathrm{W}_{\cdot, \mathrm{F}}, N^{w}=12$ waste types, the $2 \times 12$ matrix $S$, and the total amount of 12 waste types $\mathrm{x}_{\mathrm{II}}$. $\mathrm{G}_{\text {,II }}$ is calculated according to the same method used for $\mathrm{K}_{\mathrm{I}, \mathrm{II}}$.

\section{Results}

In this section, we will introduce the results of the Australian aggregation IOT of 2010-2011, the Australian WIO model, the coefficient matrices of the Australian WIO model, and the effects of 
Australian economic activities on waste treatment methods. We will then describe the physical flow of the Australian WIO models in 2009-2010 and 2010-2011.

\subsection{Interpolation and Extrapolation}

The comparative analysis of the 2010-2011 IO tables produced by interpolation and extrapolation indicates that there are substantial differences between interpolation and extrapolation. Results of regression models with their main characteristics for the 'All other industries' (AOI) sector to intermediate sectors using interpolation are shown in Table 3. Of the two aggregated Australian IOTs of 2010-2011, the table obtained by interpolation is more reasonable because we have a greater likelihood of obtaining a valid IOT of 2010-2011 based on the information before and after the year of 2010-2011. This validity of the interpolated 2010-2011 IOT over the extrapolated is due to presence of additional data (e.g., the year of 2012-2013). The key assumption made in the process of extrapolation is that the trend of data continues for the estimated data (in 2010-2011) outside the time period (2006-2010). But the trend in the real Australian economy differs from that of the extrapolated. In other words, the real Australian economy sometimes is opposite of the extrapolated forecast.

A good example of this variance between the extrapolation and interpolated predictions is the economic flow from the Mining sector to the Mining sector (Figure 1). The extrapolation predicts the MI sector would require more than $\$ 20,000$ million AUD more inputs from the MI sector in 2010-2011, yet the interpolation indicates that there was actually a decrease in inputs of approximately $\$ 400$ million AUD. Due to the uncertainty of the extrapolation, the interpolated Australian aggregation IOT of 2010-2011 (Table 4) will be used for building the Australian WIO table of 2010-2011. The extrapolated IOT is provided in Table 5 for comparison.

\subsection{The Australian Aggregation IOT of 2010-2011}

The data of the Australian IOT of 2010-2011 is interpolated and extrapolated through Equations (4) and (5). Two types of regression results from Equation (5) are discussed:

1. Adjusted $R^{2} \geq 0.50$ with $p<0.05$.

2. Adjusted $R^{2}<0.50$ with $p<0.05$.

The curve fitting of the amount of inputs from the EWG sector to the MA sector in Figure 2 depicts the first type of regression results interpolated by applying the linear regression equation. Figure 3 shows the curve fitting of the amount of inputs from the AG sector to the MI sector interpolated by applying the quadratic polynomial equation. When the $p$-value is greater than 0.05 , the inputs of IOA in 2010-2011 are estimated by those in 2009-2010 and 2012-2013. Figure 4 shows the linear regression curve of the amount of inputs from the AG sector to the $\mathrm{CO}$ sector when the second type of regression occurs. The regression models for inputs of AOI to intermediate sectors are shown in Table 3. The regression models of interpolating the Australian aggregation IOT of 2010-2011 are supplied from Table S6 to Table S13, which are available in the supplementary file. The regression models for extrapolating the Australian aggregation IOT of 2010-2011 are supplied from Table S14 to Table S22, available in the supplementary file. Ninety individual cells in the Australian IOT of 2010-2011 by interpolating and extrapolating are displayed in Tables 4 and 5, in which 82 individual cells are interpolated and extrapolated by Equations (4) and (5). The values in the row of Other final demand (except two values from Primary input to Households and Other final demand) are estimated by subtracting the sum of inputs from intermediate sectors to Households and Other final demand from Total output to balance the IOTs of 2010-2011.

The interpolation and extrapolation of the Australian aggregation IOTs of 2010-2011 are shown (see Tables 4 and 5). 


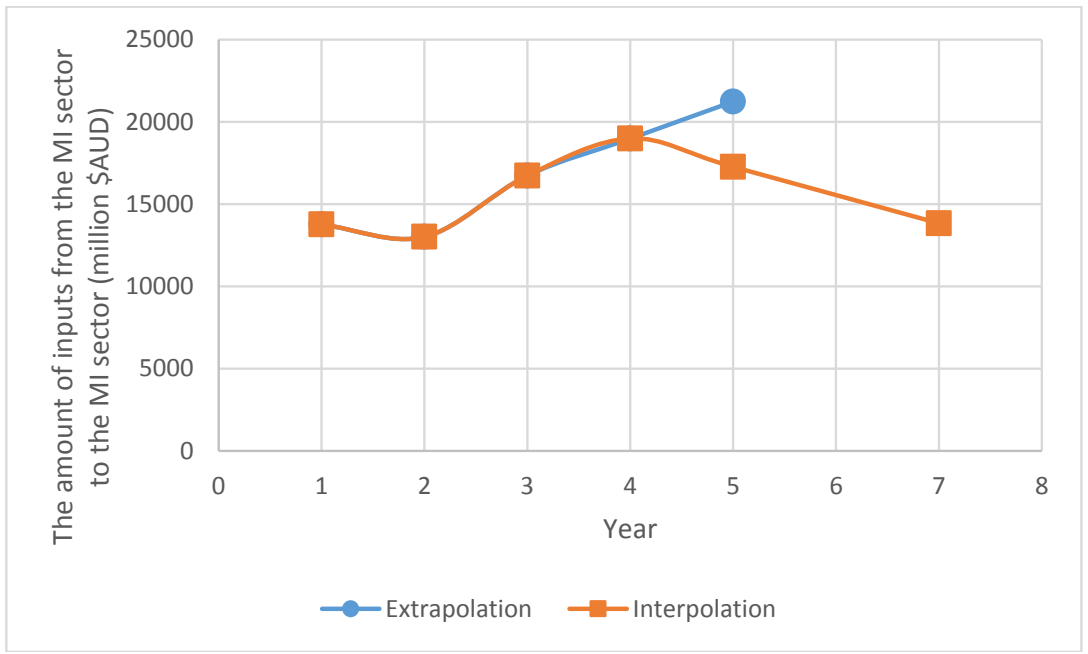

Figure 1. The comparative analysis for inputs from the MI sector to the MI sector. Mining = MI.

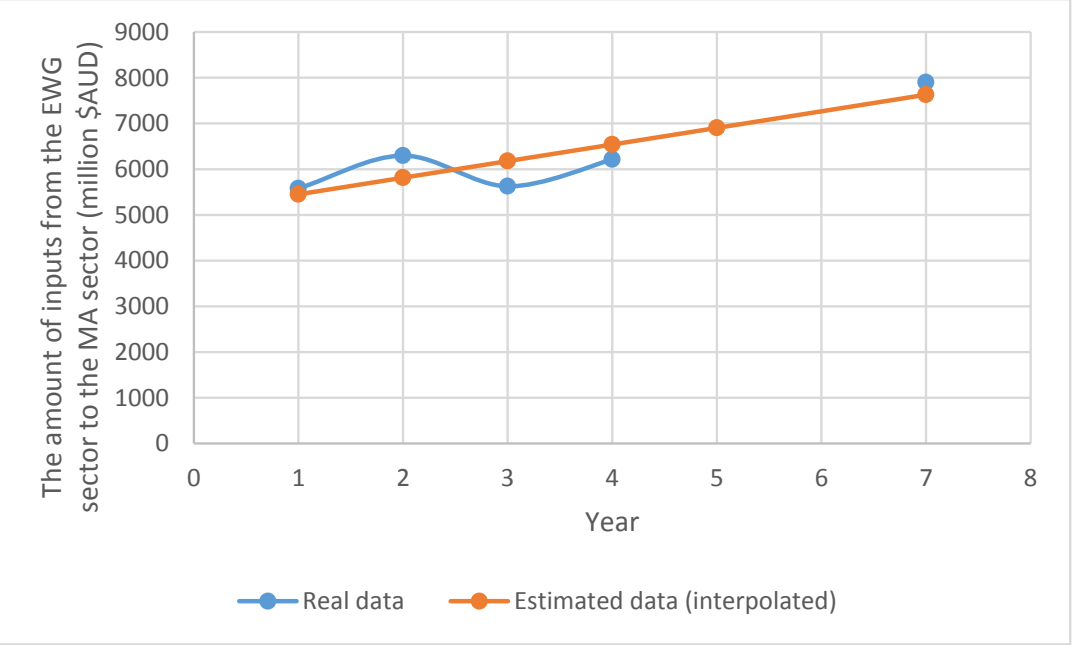

Figure 2. Inputs from the EWG sector to the MA sector (linear regression equation). Electricity, gas, and water $=\mathrm{EGW}$; Manufacturing $=$ MA.

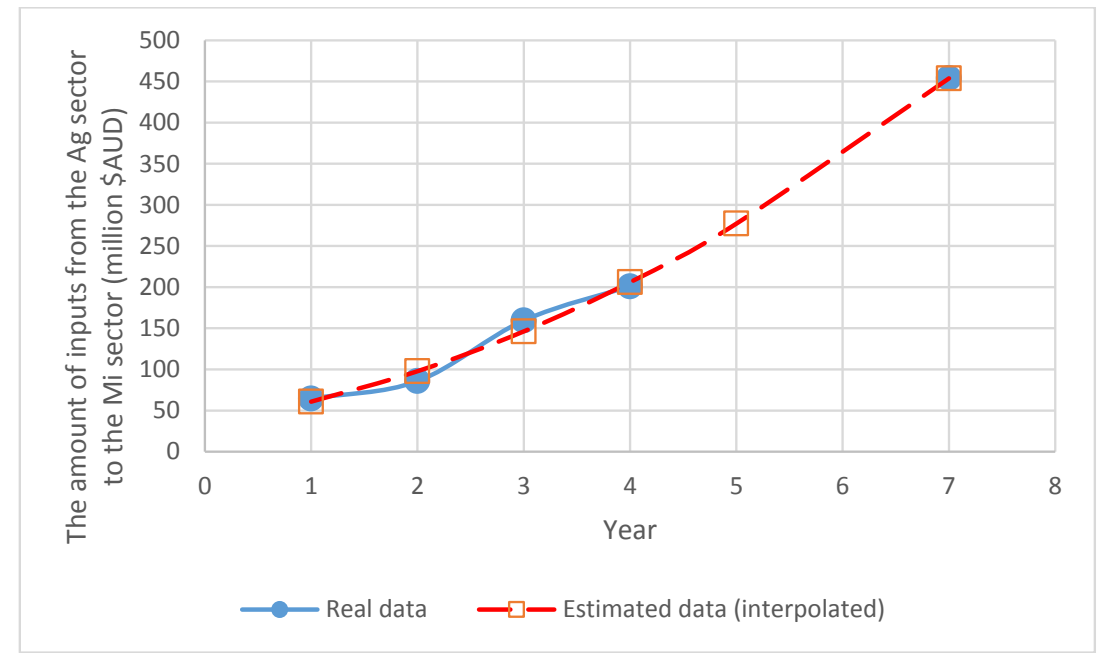

Figure 3. Inputs from the AG sector to the MI sector (quadratic polynomial equation). Agriculture, forestry, and fishing = AG; Mining = MI. 


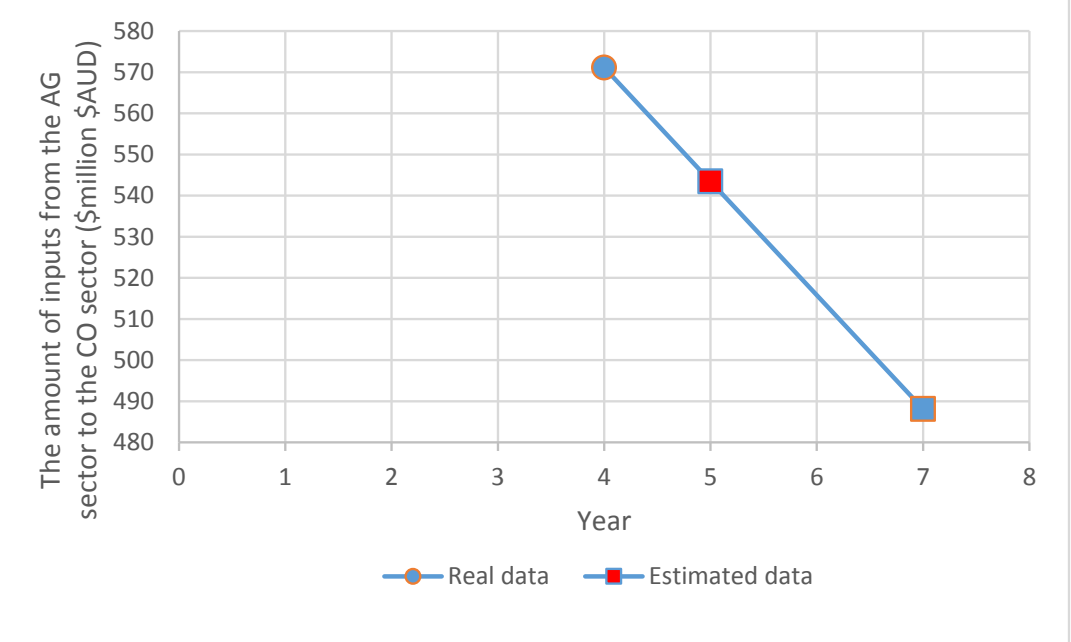

Figure 4. Inputs from the AG sector to the $\mathrm{CO}$ sector in Equation (4). Agriculture, forestry, and fishing $=\mathrm{AG}$; Construction $=\mathrm{CO}$.

Table 3. Regression models with their main characteristics for the AOI sector to intermediate sectors using interpolation, coefficients $(n=5)$.

\begin{tabular}{|c|c|c|c|c|c|}
\hline Dependent Variable & Adjusted $\mathrm{R}^{2}$ & $p$-Value & Independent Variables & Coefficient & $p$-Value \\
\hline $\mathrm{AOI}-\mathrm{AG}$ & & & $\begin{array}{l}\text { Constant } \\
\text { Year } \\
\text { Year^2 }\end{array}$ & $\begin{array}{c}12,020.47 \\
157.00\end{array}$ & \\
\hline $\mathrm{AOI}-\mathrm{MI}$ & 0.93 & 0.04 & $\begin{array}{c}\text { Constant } \\
\text { Year } \\
\text { Year } 2\end{array}$ & $\begin{array}{c}16,710.85 \\
498.02 \\
447.70\end{array}$ & \\
\hline AOI - MA & 0.97 & 0.02 & $\begin{array}{l}\text { Constant } \\
\text { Year } \\
\text { Year^2 }\end{array}$ & $\begin{array}{c}3407.40 \\
-291.97 \\
16,065.30\end{array}$ & $\begin{array}{l}0.00 \\
0.01 \\
0.01\end{array}$ \\
\hline AOI - EGW & & & $\begin{array}{l}\text { Constant } \\
\text { Year } \\
\text { Year^2 }\end{array}$ & $\begin{array}{l}1225.05 \\
1629.38\end{array}$ & \\
\hline $\mathrm{AOI}-\mathrm{CO}$ & 0.97 & 0.02 & $\begin{array}{l}\text { Constant } \\
\text { Year } \\
\text { Year^2 }\end{array}$ & $\begin{array}{c}47,997.12 \\
9079.35 \\
-826.08\end{array}$ & $\begin{array}{l}0.00 \\
0.02 \\
0.03\end{array}$ \\
\hline $\mathrm{AOI}-\mathrm{PA}$ & 1.00 & 0.00 & $\begin{array}{c}\text { Constant } \\
\text { Year } \\
\text { Year } 2\end{array}$ & $\begin{array}{c}19,642.77 \\
4131.77 \\
-271.90\end{array}$ & $\begin{array}{l}0.00 \\
0.00 \\
0.01\end{array}$ \\
\hline $\mathrm{AOI}-\mathrm{AOI}$ & 0.93 & 0.03 & $\begin{array}{l}\text { Constant } \\
\text { Year } \\
\text { Year^2 }\end{array}$ & $\begin{array}{c}355,732.03 \\
9864.20 \\
1170.11\end{array}$ & 0.00 \\
\hline AOI - WMS & 0.90 & 0.05 & $\begin{array}{l}\text { Constant } \\
\text { Year } \\
\text { Year^2 }\end{array}$ & $\begin{array}{c}193.38 \\
24.58 \\
8.96\end{array}$ & \\
\hline AOI - Households & 0.99 & 0.00 & $\begin{array}{c}\text { Constant } \\
\text { Year } \\
\text { Year^2 }\end{array}$ & $\begin{array}{c}397,352.94 \\
21,404.46 \\
1039.74\end{array}$ & 0.00 \\
\hline AOI - Other final demand & 0.99 & 0.01 & $\begin{array}{c}\text { Constant } \\
\text { Year } \\
\text { Year^2 }\end{array}$ & $\begin{array}{c}210,573.24 \\
10,616.83 \\
59.81\end{array}$ & 0.00 \\
\hline
\end{tabular}

Note: The regression models for inputs of AOI to intermediate sectors are shown in Table 3. Values of main characteristics for some dependent variables are blank because the coefficients are estimated by using the same method as in Figure 4. The $p$-values for certain coefficients were not significant because the numbers of samples were small. However, the value of adjusted $R^{2}$ is very high and the p-value is greater than 0.05 . These coefficients are still used to estimate the inputs of IO table in 2010-2011. Agriculture, forestry, and fishing = AG; Mining = MI; Manufacturing = MA; Electricity, gas, and water $=$ EGW; Waste management services $=$ WMS; Construction $=\mathrm{CO}$; Public administration $=$ PA; All other industry $=$ AOI. 
Table 4. The interpolation of Australian aggregation input-output table (IOT) of 2010-2011.

\begin{tabular}{|c|c|c|c|c|c|c|c|c|c|c|c|}
\hline & AG & MI & MA & EGW & $\mathrm{CO}$ & PA & AOI & WMS & Households & Other Final Demand & Total Output \\
\hline \multicolumn{12}{|c|}{ (Million \$AUD) } \\
\hline $\mathrm{AG}$ & $13,881.67$ & 277.23 & $24,956.53$ & 28.22 & 543.46 & 174.54 & 6054.83 & 0.84 & 6954.43 & $17,070.38$ & $69,942.13$ \\
\hline MI & 114.39 & $17,264.46$ & $33,299.39$ & 3115.48 & 2077.38 & 130.89 & 3459.11 & 3.25 & 2276.83 & $117,302.95$ & $179,044.12$ \\
\hline MA & 5059.59 & 8497.98 & $69,093.36$ & 1714.33 & $48,124.90$ & 3993.37 & $61,747.67$ & 93.42 & $66,304.29$ & $104,474.65$ & $369,103.56$ \\
\hline EGW & 1074.62 & 2813.77 & 6904.17 & $19,755.70$ & 1413.32 & 1526.03 & $12,204.49$ & 17.43 & $18,074.87$ & 7907.22 & $71,691.63$ \\
\hline $\mathrm{CO}$ & 1348.29 & 8509.97 & 2799.20 & 3882.16 & $90,890.39$ & 6384.47 & $29,401.81$ & 98.45 & 730.07 & $196,920.53$ & $340,965.34$ \\
\hline PA & 63.04 & 820.31 & 1327.40 & 153.58 & 1366.49 & 3471.88 & 9116.67 & 2.17 & 1895.53 & $123,398.92$ & $141,615.99$ \\
\hline AOI & $12,805.48$ & $30,393.45$ & $68,546.79$ & 9371.92 & $72,741.79$ & $33,503.98$ & $434,305.74$ & 540.22 & $530,368.80$ & $265,152.52$ & $1457,730.69$ \\
\hline WMS & 27.33 & 47.77 & 173.65 & 66.99 & 1561.00 & 51.43 & 952.91 & 11.29 & 568.70 & 546.92 & 4007.98 \\
\hline Primary input & $35,567.71$ & $110,419.18$ & $162,003.06$ & $33,603.26$ & $122,246.62$ & $92,379.40$ & $900,487.47$ & 3240.92 & $125,292.11$ & $87,798.18$ & $1673,037.92$ \\
\hline Total input & $69,942.13$ & $179,044.12$ & $369,103.56$ & $71,691.63$ & $340,965.34$ & $141,615.99$ & $1457,730.69$ & 4007.98 & $752,465.64$ & $920,572.28$ & $4307,139.37$ \\
\hline
\end{tabular}

Note: Agriculture, forestry, and fishing = AG; Mining = MI; Manufacturing = MA; Electricity, gas, and water = EGW; Waste management services = WMS; Construction = CO; Public

administration $=$ PA; All other industry $=$ AOI.

Table 5. The extrapolation of Australian aggregation input-output table (IOT) of 2010-2011.

\begin{tabular}{|c|c|c|c|c|c|c|c|c|c|c|c|}
\hline & AG & MI & MA & EGW & $\mathrm{CO}$ & PA & AOI & WMS & Households & Other Final Demand & Total Output \\
\hline \multicolumn{12}{|c|}{ (Million \$AUD) } \\
\hline $\mathrm{AG}$ & $15,239.59$ & 248.38 & $21,160.68$ & 47.56 & 766.92 & 185.10 & 7394.11 & 1.74 & 5834.36 & $12,608.20$ & $63,486.64$ \\
\hline MI & 50.71 & $21,226.57$ & $26,746.83$ & 2806.20 & 1942.63 & 136.21 & 3070.96 & 1.31 & 2215.65 & $85,064.27$ & $143,261.34$ \\
\hline MA & 4468.62 & 5238.63 & $68,817.91$ & 1909.33 & $43,217.27$ & 3296.43 & $60,070.67$ & 90.06 & $70,203.99$ & $94,222.78$ & $351,535.68$ \\
\hline EGW & 1159.01 & 2807.48 & 6800.11 & $21,190.00$ & 1322.33 & 676.44 & $12,830.90$ & 14.65 & $18,060.18$ & 7811.43 & $72,672.53$ \\
\hline $\mathrm{CO}$ & 749.11 & 8789.97 & 2810.18 & 5887.72 & $88,531.92$ & 7827.37 & $33,668.38$ & 267.78 & 741.95 & $185,690.64$ & $334,965.01$ \\
\hline PA & 64.79 & 514.25 & 1443.19 & 179.91 & 1209.16 & 3157.81 & 9018.64 & 1.79 & 1968.98 & $103,499.94$ & $121,058.45$ \\
\hline AOI & $11,379.83$ & $22,194.22$ & $69,048.42$ & 8762.07 & $76,710.06$ & $32,406.08$ & $410,306.14$ & 352.29 & $523,600.10$ & $254,855.82$ & $1,409,615.03$ \\
\hline WMS & 1.03 & 54.86 & 139.49 & 57.22 & 2306.32 & 34.58 & 324.49 & 0.01 & 782.53 & 424.18 & 4124.73 \\
\hline Primary input & $30,373.95$ & $82,186.97$ & $154,568.86$ & $31,832.52$ & $118,958.40$ & $73,338.45$ & $872,930.74$ & 3395.11 & $118,929.80$ & $78,648.38$ & $1,565,163.17$ \\
\hline Total input & $63,486.64$ & $14,3261.34$ & $351,535.68$ & $72,672.53$ & $334,965.01$ & $121,058.45$ & $140,9615.03$ & 4124.73 & $742,337.54$ & $822,825.63$ & $4,065,882.57$ \\
\hline
\end{tabular}

Note: Agriculture, forestry, and fishing = AG; Mining = MI; Manufacturing = MA; Electricity, gas, and water = EGW; Waste management services = WMS; Construction = CO; Public administration $=$ PA; All other industry = AOI. 


\subsection{Tables of Australian WIO in 2009-2010 and 2010-2011}

The authors compiled two Australian WIOTs based on the WIO framework, the Australian aggregation IOTs of 2009-2010 and 2010-2011, and the corresponding waste generation accounts during the period (see Tables 6 and 7).

Note that an Australian WIO table consists of the elements appearing in Equation (1). In Tables 6 and 7 , the $7 \times 7$ matrix of intermediate sectors $\times$ intermediate sectors in the upper left-hand corner corresponds to $\mathrm{K}$, the $7 \times 2$ matrix of Intermediate sectors $\times$ waste treatment methods in the upper right-hand corner corresponds to K, SG., located in the lower left-hand corner corresponds to the $2 \times 7$ matrix of types of waste treatment methods $\times$ intermediate sectors, and SG., in the lower right-hand corner is the $2 \times 2$ matrix of types of waste treatment methods $\times$ waste treatment methods. $\mathrm{K}$, and $\mathrm{K}$, are measured in a monetary unit (million \$AUD) while SG., and SG., are measured in a physical unit (1000 tonnes).

The hybrid WIO models with the same rows and columns in squared matrices were built, which incorporate the monetary and physical information regarding Australian economic activities and waste treatment methods. The amount of waste generated by intermediate sectors and treated by two types of waste treatment methods are shown in Table 6 (2009-2010) and Table 7 (2010-2011). Therefore, we will provide information for the Construction sector in the WIO mode in detail. Table 6 shows that the total inputs of 313,634.00 million \$AUD goods to the Construction sector are offered by intermediate sectors, which generates 8205.45 (1000 tonnes) to the Landfill sector and 7849.80 (1000 tonnes) to the Recovery sector in 2009-2010. Although the total inputs of the Construction sector increase to 340,965.34 million \$AUD, the amount of waste generated by the Construction sector decrease to 6781.24 (1000 tonnes) to the Landfill sector and 7709.83 (1000 tonnes) to the Recovery sector in 2010-2011 (see Table 7).

\subsection{Coefficient Matrices of the Australian WIO Model}

From Tables 6 and 7 the input coefficients matrices in 2009-2010 and 2010-2011 (see Tables 8 and 9) can be obtained by Equation (2). Tables 8 and 9 display the amount of waste generated by each million \$AUD of output of intermediate sectors and treated by waste treatment sectors.

For example, per million \$AUD of output of the Construction sector generated the largest amount of direct and total waste in both 2009-2010 and 2010-2011 in intermediate sectors. Table 8 shows per million \$AUD of output of the Construction sector directly generated 51.2 tonnes waste in 2009-2010, and also require sources from intermediate sectors (direct):

- 0.0018 million \$AUD inputs from the Agriculture, forestry, and fishing sector

- 0.0045 million \$AUD inputs from the Mining sector

- $\quad 0.1407$ million \$AUD inputs from the Manufacturing sector

- $\quad 0.0042$ million \$AUD inputs from the Electricity, gas, and water sector

- 0.2596 million \$AUD inputs from the Construction sector

- 0.0035 million \$AUD inputs from the Public administration sector

- 0.2264 million \$AUD inputs from the All other industry sector.

The output of these sources indirectly generates the amount of waste. The inverse coefficients referring to the sum of both direct and indirect effects of intermediate sectors are calculated according to Equation (3). The results of Equation (3) are shown in Tables 10 and 11. The Construction sector has the largest inverse coefficients of waste generation followed by the Public administration sector. For example, each million \$AUD of output of the Construction sector in Australia in 2009-2010 requires total inputs of:

- $\quad 0.0297$ million \$AUD inputs from the Agriculture, forestry, and fishing sector

- 0.0345 million \$AUD inputs from the Mining sector

- 0.2781 million \$AUD inputs from the Manufacturing sector 
Table 6. The Australian waste input output (WIO) table with waste treatment methods, 2009-2010.

\begin{tabular}{|c|c|c|c|c|c|c|c|c|c|c|c|c|}
\hline & AG & MI & MA & EGW & $\mathrm{CO}$ & PA & AOI & Landfill & Recovery & Households & Other Final Demand & Total Output \\
\hline & \multicolumn{12}{|c|}{ (Million \$AUD) } \\
\hline $\mathrm{AG}$ & $13,420.64$ & 200.87 & $24,772.39$ & 34.25 & 571.12 & 175.60 & 6784.67 & 0.57 & 0.43 & 6450.11 & $13,467.36$ & $65,878.00$ \\
\hline MI & 64.29 & $18,979.43$ & $29,647.24$ & 3426.72 & 1399.34 & 99.48 & 2826.65 & 0.81 & 0.61 & 2108.02 & $10,3962.42$ & $162,515.00$ \\
\hline MA & 5099.91 & 7253.39 & $72,764.32$ & 1899.70 & $44,135.63$ & 4383.00 & $64,633.10$ & 58.66 & 44.25 & $67,206.87$ & $10,6187.19$ & $373,666.00$ \\
\hline EGW & 1057.32 & 2499.78 & 6213.25 & $17,311.37$ & 1304.40 & 633.32 & $11,422.44$ & 7.89 & 5.95 & $16,277.28$ & 7493.00 & $64,226.00$ \\
\hline $\mathrm{CO}$ & 1104.48 & 7569.35 & 3049.72 & 4266.23 & $81,429.02$ & 6760.20 & $29,083.91$ & 79.18 & 59.74 & 716.71 & $17,9515.46$ & $313,634.00$ \\
\hline PA & 62.82 & 520.55 & 1275.65 & 150.54 & 1100.35 & 3184.70 & 8717.94 & 1.29 & 0.97 & 1933.61 & $98,802.58$ & $115,751.00$ \\
\hline AOI & $12,648.48$ & $23,691.54$ & $69,747.18$ & 7742.55 & $71,020.60$ & $31,563.06$ & $40,4647.88$ & 222.25 & 167.67 & $49,7319.66$ & $25,1529.13$ & $1,370,300.00$ \\
\hline $\begin{array}{l}\text { Treatment } \\
\text { methods }\end{array}$ & \multicolumn{12}{|c|}{ (units: 000 tonnes) } \\
\hline Landfill & 1163.69 & 180.45 & 4667.27 & 501.17 & 8205.45 & 475.88 & 6829.83 & 12.09 & 9.00 & 7204.62 & 0 & $29,249.45$ \\
\hline Recovery & 741.32 & 86.71 & 4882.03 & 400.75 & 7849.80 & 371.56 & 4350.84 & 7.17 & 5.35 & 5254.03 & 365.03 & $27,602.59$ \\
\hline
\end{tabular}

Note: Agriculture, forestry, and fishing = AG; Mining = MI; Manufacturing = MA; Electricity, gas, and water = EGW; Waste management services = WMS; Construction = CO; Public administration $=\mathrm{PA}$; All other industry $=\mathrm{AOI}$.

Table 7. The interpolated Australian waste input output (WIO) table with waste treatment methods, 2010-2011.

\begin{tabular}{|c|c|c|c|c|c|c|c|c|c|c|c|c|}
\hline & AG & MI & MA & EGW & $\mathrm{CO}$ & PA & AOI & Landfill & Recovery & Households & Other Final Demand & Total Output \\
\hline & \multicolumn{12}{|c|}{ (Million \$AUD) } \\
\hline AG & $13,881.67$ & 277.23 & $24,956.53$ & 28.22 & 543.46 & 174.54 & 6054.83 & 0.48 & 0.36 & 6954.43 & $17,070.38$ & $69,942.13$ \\
\hline MI & 114.39 & $17,264.46$ & $33,299.39$ & 3115.48 & 2077.38 & 130.89 & 3459.11 & 1.87 & 1.38 & 2276.83 & $117,302.90$ & $179,044.12$ \\
\hline MA & 5059.59 & 8497.98 & $69,093.36$ & 1714.33 & $48,124.90$ & 3993.37 & $61,747.67$ & 53.71 & 39.70 & $66,304.29$ & $104,474.60$ & $369,103.56$ \\
\hline EGW & 1074.62 & 2813.77 & 6904.18 & $19,755.70$ & 1413.32 & 1526.03 & $12,204.49$ & 10.02 & 7.41 & $18,074.87$ & 7907.22 & $71,691.63$ \\
\hline $\mathrm{CO}$ & 1348.29 & 8509.97 & 2799.20 & 3882.16 & $90,890.39$ & 6384.47 & $29,401.81$ & 56.61 & 41.84 & 730.07 & $196,920.50$ & $340,965.34$ \\
\hline PA & 63.04 & 820.31 & 1327.41 & 153.58 & 1366.49 & 3471.88 & 9116.67 & 1.25 & 0.92 & 1895.53 & $123,398.90$ & $141,615.99$ \\
\hline AOI & $12,805.48$ & $30,393.45$ & $68,546.79$ & 9371.92 & $72,741.79$ & $33,503.98$ & $434,305.70$ & 310.63 & 229.59 & $530,368.80$ & $265,152.50$ & $1457,730.70$ \\
\hline $\begin{array}{l}\text { Treatment } \\
\text { methods }\end{array}$ & \multicolumn{12}{|c|}{ (units: 000 tonnes) } \\
\hline Landfill & 1323.11 & 375.42 & 4817.43 & 338.26 & 6781.24 & 322.16 & 5787.22 & 9.00 & 6.67 & 8429.86 & 0.00 & $28,190.37$ \\
\hline Recovery & 681.33 & 230.48 & 4775.18 & 385.85 & 7709.83 & 367.39 & 4160.47 & 6.72 & 4.99 & 5838.78 & 3677.05 & 27838.07 \\
\hline
\end{tabular}

Note: Agriculture, forestry, and fishing = AG; Mining = MI; Manufacturing = MA; Electricity, gas, and water = EGW; Waste management services = WMS; Construction = CO; Public

administration $=$ PA; All other industry $=$ AOI. 
- 0.0218 million \$AUD inputs from the Electricity, gas, and water sector

- 1.3750 million \$AUD inputs from the Construction sector

- 0.0097 million \$AUD inputs from the Public administration sector

- 0.5390 million \$AUD inputs from the All other industry sector.

In addition, each million \$AUD of total output of the Construction sector generated a total amount of 42.9 tonnes of waste to the Landfill sector and 40.3 tonnes of waste to the Recovery sector.

As for waste treatment sectors, the column of the Landfill sector placing into landfill each thousand tonnes of waste requires a direct input of 0.0020 million \$AUD from the Manufacturing sector, 0.0003 million \$AUD from the Electricity, gas, and water sector, 0.0027 million \$AUD from the Construction sector, and 0.0076 million \$AUD from the All other intermediate sector in 2009-2010.

Meanwhile, the column of the Recovery sector in Table 8 indicates that recovering each thousand tonnes of waste direct requires the input of 0.0016 million \$AUD from the Manufacturing sector, 0.0002 million \$AUD from the Electricity, gas, and water sector, 0.0022 million \$AUD from the Construction sector, and 0.0061 million \$AUD from the All other intermediate sector. This result shows that the Landfill sector consumed more resources to treat per thousand tonnes of waste than the Recovery sector did.

Table 8. The input coefficient matrix of Australian waste input output (WIO) table with waste treatment methods, 2009-2010.

\begin{tabular}{|c|c|c|c|c|c|c|c|c|c|}
\hline & AG & MI & MA & EGW & $\mathrm{CO}$ & PA & AOI & Landfill & Recovery \\
\hline \multicolumn{10}{|c|}{$\begin{array}{l}\text { Products and services input coefficients (units: million \$AUD per million \$AUD of output for intermediate } \\
\text { sectors, million \$AUD per } 1000 \text { tonnes of waste for waste treatment sectors) }\end{array}$} \\
\hline AG & 0.2037 & 0.0012 & 0.0663 & 0.0005 & 0.0018 & 0.0015 & 0.0050 & 0.0000 & 0.0000 \\
\hline MI & 0.0010 & 0.1168 & 0.0793 & 0.0534 & 0.0045 & 0.0009 & 0.0021 & 0.0000 & 0.0000 \\
\hline MA & 0.0774 & 0.0446 & 0.1947 & 0.0296 & 0.1407 & 0.0379 & 0.0472 & 0.0020 & 0.0016 \\
\hline EGW & 0.0160 & 0.0154 & 0.0166 & 0.2695 & 0.0042 & 0.0055 & 0.0083 & 0.0003 & 0.0002 \\
\hline $\mathrm{CO}$ & 0.0168 & 0.0466 & 0.0082 & 0.0664 & 0.2596 & 0.0584 & 0.0212 & 0.0027 & 0.0022 \\
\hline PA & 0.0010 & 0.0032 & 0.0034 & 0.0023 & 0.0035 & 0.0275 & 0.0064 & 0.0000 & 0.0000 \\
\hline AOI & 0.1920 & 0.1458 & 0.1867 & 0.1206 & 0.2264 & 0.2727 & 0.2953 & 0.0076 & 0.0061 \\
\hline
\end{tabular}

Treatment input coefficients (units: 1000 tonnes per million AUS dollar of output for intermediate sectors, 1000 tonnes per 1000 tonnes of waste for waste treatment sectors)

\begin{tabular}{llllllllll}
\hline Landfill & 0.0177 & 0.0011 & 0.0125 & 0.0078 & 0.0262 & 0.0041 & 0.0050 & 0.0004 & 0.0003 \\
Recovery & 0.0113 & 0.0005 & 0.0131 & 0.0062 & 0.0250 & 0.0032 & 0.0032 & 0.0002 & 0.0002 \\
\hline
\end{tabular}

Note: value $<0.0001$ are not displayed for the sake of readability. Agriculture, forestry, and fishing = AG; Mining = MI; Manufacturing = MA; Electricity, gas, and water = EGW; Waste management services = WMS; Construction $=\mathrm{CO}$; Public administration $=\mathrm{PA} ;$ All other industry $=$ AOI

Table 9. The input coefficient matrix of Australian waste input output (WIO) table with waste treatment methods, 2010-2011.

\begin{tabular}{|c|c|c|c|c|c|c|c|c|c|}
\hline & AG & MI & MA & EGW & $\mathrm{CO}$ & PA & AOI & Landfill & Recovery \\
\hline \multicolumn{10}{|c|}{$\begin{array}{l}\text { Products and services input coefficients (units: million \$AUD per million \$AUD of output for intermediate } \\
\text { sectors, million \$AUD per } 1000 \text { tonnes of waste for waste treatment sectors) }\end{array}$} \\
\hline $\mathrm{AG}$ & 0.1985 & 0.0015 & 0.0676 & 0.0004 & 0.0016 & 0.0012 & 0.0042 & 0.0000 & 0.0000 \\
\hline MI & 0.0016 & 0.0964 & 0.0902 & 0.0435 & 0.0061 & 0.0009 & 0.0024 & 0.0001 & 0.0000 \\
\hline MA & 0.0723 & 0.0475 & 0.1872 & 0.0239 & 0.1411 & 0.0282 & 0.0424 & 0.0019 & 0.0014 \\
\hline EGW & 0.0154 & 0.0157 & 0.0187 & 0.2756 & 0.0041 & 0.0108 & 0.0084 & 0.0004 & 0.0003 \\
\hline $\mathrm{CO}$ & 0.0193 & 0.0475 & 0.0076 & 0.0542 & 0.2666 & 0.0451 & 0.0202 & 0.0020 & 0.0015 \\
\hline PA & 0.0009 & 0.0046 & 0.0036 & 0.0021 & 0.0040 & 0.0245 & 0.0063 & 0.0000 & 0.0000 \\
\hline AOI & 0.1831 & 0.1698 & 0.1857 & 0.1307 & 0.2133 & 0.2366 & 0.2979 & 0.0110 & 0.0082 \\
\hline
\end{tabular}


Table 9. Cont.

\begin{tabular}{|c|c|c|c|c|c|c|c|c|c|}
\hline & AG & MI & MA & EGW & $\mathrm{CO}$ & PA & AOI & Landfill & Recovery \\
\hline \multicolumn{10}{|c|}{$\begin{array}{l}\text { Treatment input coefficients (units: } 1000 \text { tonnes per million AUS dollar of output for intermediate sectors, } \\
1000 \text { tonnes per } 1000 \text { tonnes of waste for waste treatment sectors) }\end{array}$} \\
\hline Landfill & 0.0189 & 0.0021 & 0.0131 & 0.0047 & 0.0199 & 0.0023 & 0.0040 & 0.0003 & 0.0002 \\
\hline Recovery & 0.0097 & 0.0013 & 0.0129 & 0.0054 & 0.0226 & 0.0026 & 0.0029 & 0.0002 & 0.0002 \\
\hline
\end{tabular}

Table 10. The Leontief inverse matrix of the Australian waste input output (WIO) analysis, 2009-2010.

\begin{tabular}{|c|c|c|c|c|c|c|c|c|c|}
\hline & AG & MI & MA & EGW & $\mathrm{CO}$ & PA & AOI & Landfill & Recovery \\
\hline \multicolumn{10}{|c|}{$\begin{array}{c}\text { (units: million \$AUD per million \$AUD of output for intermediate sectors, million \$AUD per } 1000 \text { tonnes of } \\
\text { waste for waste treatment sectors) }\end{array}$} \\
\hline $\mathrm{AG}$ & 1.2717 & 0.0121 & 0.1106 & 0.0119 & 0.0297 & 0.0131 & 0.0175 & 0.0005 & 0.0004 \\
\hline MI & 0.0190 & 1.1441 & 0.1198 & 0.0939 & 0.0345 & 0.0122 & 0.0138 & 0.0005 & 0.0004 \\
\hline MA & 0.1577 & 0.0986 & 1.2928 & 0.1016 & 0.2781 & 0.0956 & 0.0984 & 0.0041 & 0.0033 \\
\hline EGW & 0.0370 & 0.0306 & 0.0395 & 1.3782 & 0.0218 & 0.0163 & 0.0201 & 0.0007 & 0.0005 \\
\hline $\mathrm{CO}$ & 0.0475 & 0.0853 & 0.0407 & 0.1411 & 1.3750 & 0.0984 & 0.0473 & 0.0042 & 0.0034 \\
\hline PA & 0.0048 & 0.0065 & 0.0080 & 0.0067 & 0.0097 & 1.0321 & 0.0103 & 0.0002 & 0.0001 \\
\hline AOI & 0.4161 & 0.3013 & 0.4207 & 0.3336 & 0.5390 & 0.4654 & 1.4755 & 0.0137 & 0.0109 \\
\hline \multicolumn{10}{|c|}{$\begin{array}{l}\text { Treatment input coefficients (units: } 1000 \text { tonnes per million AUS dollar of output for intermediate sectors, } \\
\qquad 1000 \text { tonnes per } 1000 \text { tonnes of waste for waste treatment sectors) }\end{array}$} \\
\hline Landfill & 0.0281 & 0.0067 & 0.0218 & 0.0177 & 0.0429 & 0.0107 & 0.0104 & 1.0007 & 0.0005 \\
\hline Recovery & 0.0191 & 0.0053 & 0.0208 & 0.0147 & 0.0403 & 0.0088 & 0.0075 & 0.0005 & 1.0004 \\
\hline
\end{tabular}

Note: value $<0.0001$ are not displayed for the sake of readability. Agriculture, forestry, and fishing = AG; Mining = MI; Manufacturing = MA; Electricity, gas, and water = EGW; Waste management services = WMS; Construction $=\mathrm{CO} ;$ Public administration $=\mathrm{PA} ;$ All other industry $=$ AOI.

Table 11. The Leontief inverse matrix of the Australian waste input output (WIO) analysis, 2010-2011.

\begin{tabular}{|c|c|c|c|c|c|c|c|c|c|}
\hline & AG & MI & MA & EGW & $\mathrm{CO}$ & PA & AOI & Landfill & Recovery \\
\hline \multicolumn{10}{|c|}{$\begin{array}{c}\text { (units: million \$AUD per million \$AUD of output for intermediate sectors, million \$AUD per } 1000 \text { tonnes of } \\
\text { waste for waste treatment sectors) }\end{array}$} \\
\hline AG & 1.2620 & 00126 & 01104 & & 0.0286 & 0.0099 & 0.0152 & 0.0005 & 0.0003 \\
\hline MI & & & & & & & & & \\
\hline MA & 0 . & 2 & 1.2 & 0.0849 & 0.2738 & 0.0722 & 0.0879 & & 0.0030 \\
\hline EGW & 0.0359 & 0.0316 & 0.0435 & 1.3892 & 0.0226 & 0.0227 & 0.0204 & 0.0009 & 0.0006 \\
\hline $\mathrm{CO}$ & 0.0499 & 0.0860 & 0.0401 & 0.1185 & 1.3863 & 0.0776 & 0.0450 & 0.0034 & 0.0026 \\
\hline PA & 0.0046 & 0.0082 & 0.0084 & 0.0064 & 0.0103 & 1.0284 & 0.0101 & 0.0002 & 0.0001 \\
\hline AOI & 0.3960 & 0.3355 & 0.4224 & 0.3409 & 0.5193 & 0.3989 & 1.4760 & 0.0183 & 0.0137 \\
\hline
\end{tabular}

Treatment input coefficients (units: 1000 tonnes per million AUS dollar of output for intermediate sectors, 1000 tonnes per 1000 tonnes of waste for waste treatment sectors)

\begin{tabular}{llllllllll}
\hline Landfill & 0.0286 & 0.0071 & 0.0218 & 0.0117 & 0.0340 & 0.0067 & 0.0083 & 1.0005 & 0.0004 \\
Recovery & 0.0167 & 0.0060 & 0.0202 & 0.0124 & 0.0369 & 0.0067 & 0.0067 & 0.0004 & 1.0003 \\
\hline
\end{tabular}

Note: value < 0.0001 are not displayed for the sake of readability. Agriculture, forestry, and fishing = AG;

Mining = MI; Manufacturing = MA; Electricity, gas, and water = EGW; Waste management services = WMS;

Construction $=\mathrm{CO} ;$ Public administration $=\mathrm{PA} ;$ All other industry $=$ AOI

\subsection{The Differences of Direct and Total Effects of Intermediate Sectors on Waste Treatment Methods}

The differences in the sum of direct effects of intermediate sectors on 7 types of intermediate sectors are determined by summing the values of the direct effects of intermediate sectors on 7 types of intermediate sectors in 2010-2011 minus those in 2009-2010. Differences in the sum of total effects of intermediate sectors on 7 types of intermediate sectors are calculated in the same way. Differences 
of the amount of waste generated by 7 types of intermediate sectors are calculated by subtracting the amount of waste generated in 2009-2010 from that generated in 2010-2011.

Figures 5 and 6 show that an increase or decrease in the Australian economy has a direct impact on waste generation. For example, when the difference in the sum of direct or total inputs of intermediate sectors on the MI sector is positive, the difference of the amount of waste generated by the MI sector is also positive. The differences in the sum of direct or total inputs of intermediate sectors for the PA sector is negative, and the difference in the amount of waste directly or totally generated in the PA sector is also negative.

The differences in the direct effects on waste treatment methods are calculated as the direct effects from intermediate sectors on waste treatment methods in 2010-2011 minus those in 2009-2010. Differences in the total effects on waste treatment methods are calculated in the same way.

Table 12 describes the differences of direct and total effects of intermediate sectors on the Landfill sector of waste treatment. It indicates that the direct effects on the Landfill sector increase in three intermediate sectors including the Agriculture, forestry, and fishing sector, the Mining sector, and the Manufacturing sector, while there is a decrease in other four sectors during the two years. The total effects on the Landfill sector show the same trend in this period.

In Table 13, the direct and total effects on the Recovery sector only increase in the Mining sector, while there is a decrease in the other intermediate sectors.

Both the sums of direct and total effects of intermediate sectors on the Landfill sector and the Recovery sector during the two years show a decreasing trend. Meanwhile, the drop of the sums of direct and total effects on the Landfill sector is greater than that on the Recovery sector.

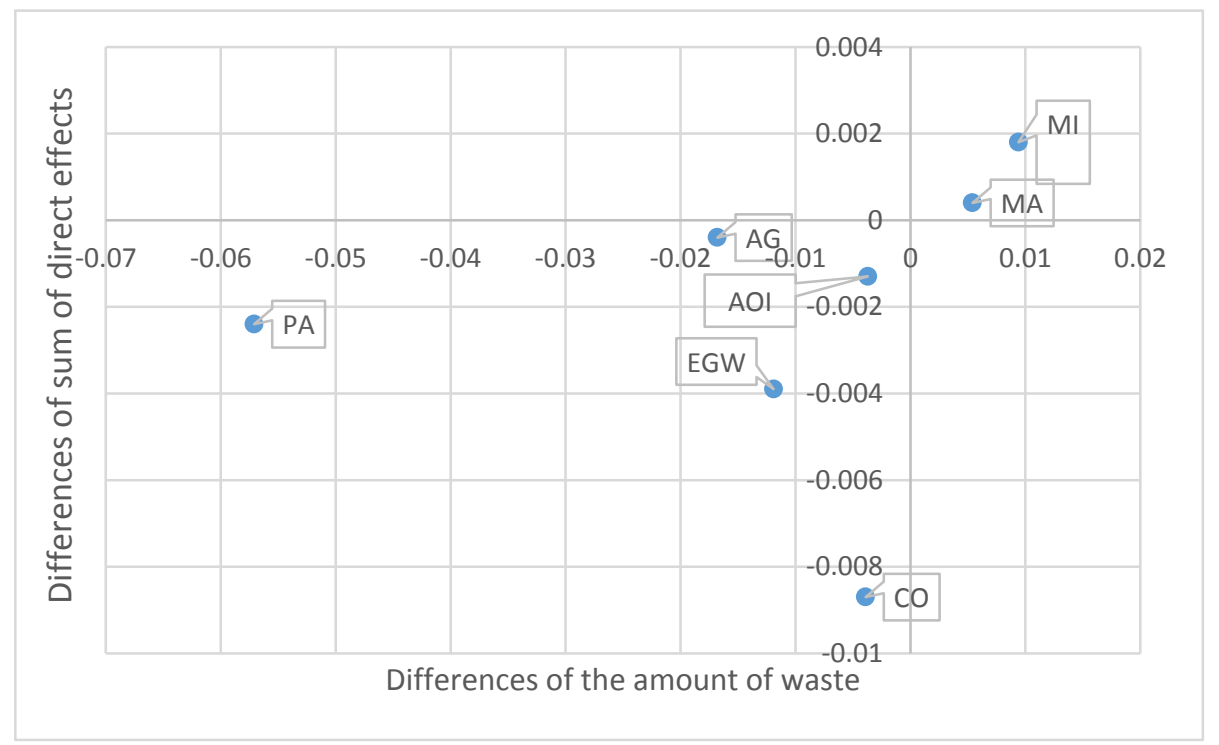

Figure 5. Relationships between differences of sum of direct effects and the amount of waste generation in various sectors of the Australian economy, YEAR. Agriculture, forestry, and fishing = AG; Mining = MI; Manufacturing = MA; Electricity, gas, and water = EGW; Waste management services $=$ WMS; Construction $=$ CO; Public administration $=$ PA; All other industry = AOI. 


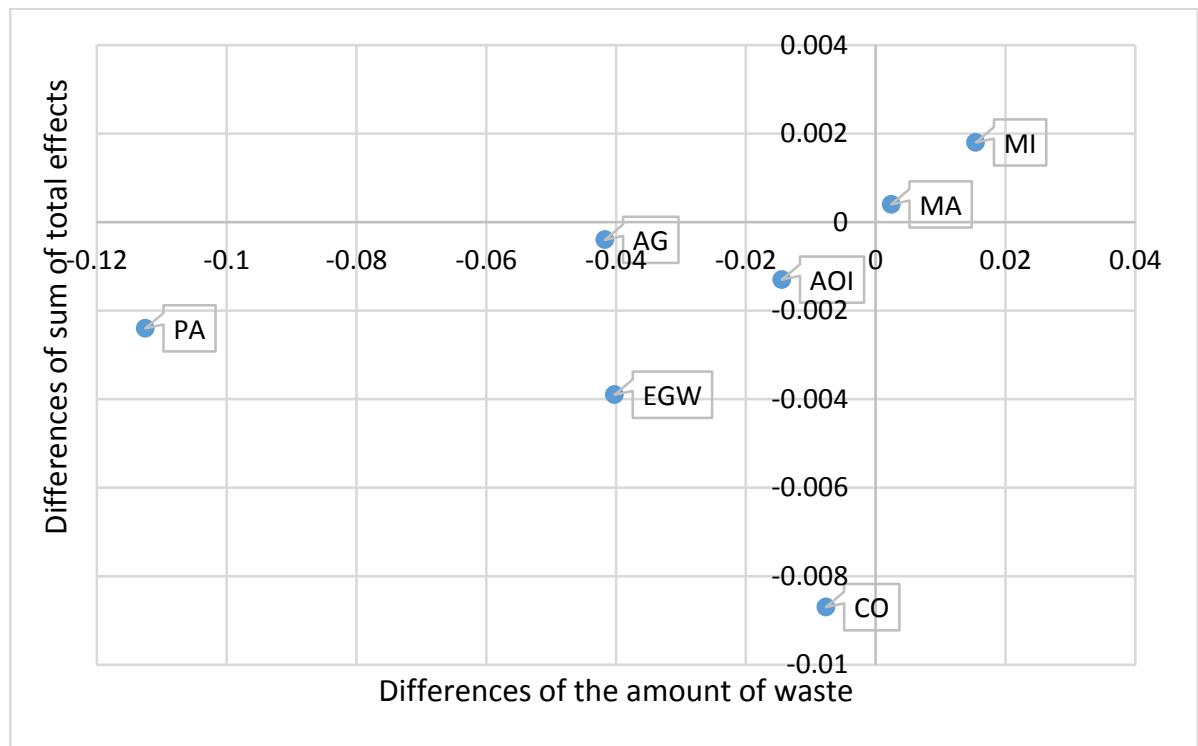

Figure 6. Relationships between differences of sum of total effects and the amount of waste generation in various sectors of the Australian economy, YEAR. Agriculture, forestry, and fishing = AG; Mining = MI; Manufacturing = MA; Electricity, gas, and water = EGW; Waste management services $=$ WMS; Construction $=\mathrm{CO} ;$ Public administration $=$ PA; All other industry $=$ AOI.

Table 12. Direct, total, and the change of direct and total effects of sectors on waste treatment method (Landfill) in the Australian economy.

\begin{tabular}{|c|c|c|c|c|c|c|}
\hline & \multicolumn{2}{|c|}{ Direct Effects } & \multirow{2}{*}{$\begin{array}{l}\text { Differences of } \\
\text { Direct Effects }\end{array}$} & \multicolumn{2}{|c|}{ Total Effects } & \multirow{2}{*}{$\begin{array}{c}\text { Differences of } \\
\text { Total Effects }\end{array}$} \\
\hline & 2009-2010 & 2010-2011 & & 2009-2010 & 2010-2011 & \\
\hline \multicolumn{7}{|c|}{ (units: 1000 tonnes per million $\$$ AUD of output for intermediate sectors) } \\
\hline AG & 0.0177 & 0.0189 & 0.0012 & 0.0281 & 0.0286 & 0.0005 \\
\hline MI & 0.0011 & 0.0021 & 0.0010 & 0.0067 & 0.0071 & 0.0004 \\
\hline MA & 0.0125 & 0.0131 & 0.0006 & 0.0218 & 0.0218 & 0.0000 \\
\hline EGW & 0.0078 & 0.0047 & -0.0031 & 0.0177 & 0.0117 & -0.0060 \\
\hline $\mathrm{CO}$ & 0.0262 & 0.0199 & -0.0063 & 0.0429 & 0.0340 & -0.0089 \\
\hline PA & 0.0041 & 0.0023 & -0.0018 & 0.0107 & 0.0067 & -0.0040 \\
\hline AOI & 0.0050 & 0.0040 & -0.0010 & 0.0104 & 0.0083 & -0.0021 \\
\hline Sum & 0.0744 & 0.0650 & -0.0094 & 0.1383 & 0.1182 & -0.0201 \\
\hline
\end{tabular}

Note: Agriculture, forestry, and fishing = AG; Mining = MI; Manufacturing = MA; Electricity, gas, and water = EGW; Waste management services $=$ WMS; Construction $=$ CO; Public administration $=$ PA; All other industry $=$ AOI .

Table 13. Direct, total, and the change of direct and total effects of sectors on waste treatment method (Recovery) in the Australian economy.

\begin{tabular}{ccccccc}
\hline & \multicolumn{2}{c}{ Direct Effects } & Differences of & \multicolumn{2}{c}{ Total Effects } & \multicolumn{2}{c}{$\begin{array}{c}\text { Differences of } \\
\text { Total Effects }\end{array}$} \\
\cline { 2 - 3 } & $\mathbf{2 0 0 9 - 2 0 1 0}$ & $\mathbf{2 0 1 0 - 2 0 1 1}$ & Direct Effects & 2009-2010 & 2010-2011 & \\
\hline AG & 0.0113 & 0.0097 & -0.0016 & 0.0191 & 0.0167 & -0.0024 \\
MI & 0.0005 & 0.0013 & 0.0008 & 0.0053 & 0.0060 & 0.0007 \\
MA & 0.0131 & 0.0129 & -0.0002 & 0.0208 & 0.0202 & -0.0006 \\
EGW & 0.0062 & 0.0054 & -0.0008 & 0.0147 & 0.0124 & -0.0023 \\
CO & 0.025 & 0.0226 & -0.0024 & 0.0403 & 0.0369 & -0.0034 \\
PA & 0.0032 & 0.0026 & -0.0006 & 0.0088 & 0.0067 & -0.0021 \\
AOI & 0.0032 & 0.0029 & -0.0003 & 0.0075 & 0.0067 & -0.0008 \\
Sum & 0.0625 & 0.0574 & -0.0051 & 0.1165 & 0.1056 & -0.0109 \\
\hline
\end{tabular}

Note: Agriculture, forestry, and fishing = AG; Mining = MI; Manufacturing = MA; Electricity, gas, and water = EGW; Waste management services = WMS; Construction = CO; Public administration = PA; All other industry = AOI. 


\subsection{Physical Flow of Waste Footprint}

The physical flow of the waste footprint shows the origin and destination of 12 types of waste.

Figures 7 and 8 depict physical flow of the waste footprint in the Australian economy in 2009-2010 and 2010-2011. From left to right, the figures show the amount of waste generated by intermediate sectors and the Households sector, the amount of 12 types of waste, and the amount of waste disposed by waste treatment methods. The amount of waste generated by intermediate sectors on the left-hand

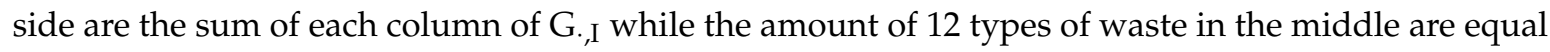
to the sum of each row of G.,I. The right-hand side are corresponding to the sum of SG.,I, SG.,II, and SW.,F. For example, the major component of Org is generated by the Households sector, and almost $50 \%$ of Org is landfilled in 2009-2010.

Figures 7 and 8 show the direct waste generation in million tonnes ( $M$ tonnes), with the largest amount of waste generated by the Construction sector (16.0553 $\mathrm{M}$ tonnes) accounting for $30.18 \%$ of total waste. The next largest amount of waste is generated by the Households sector (23.42\%) followed by the All other industry sector (21.02\%) in 2009-2010 (see Figure 7).

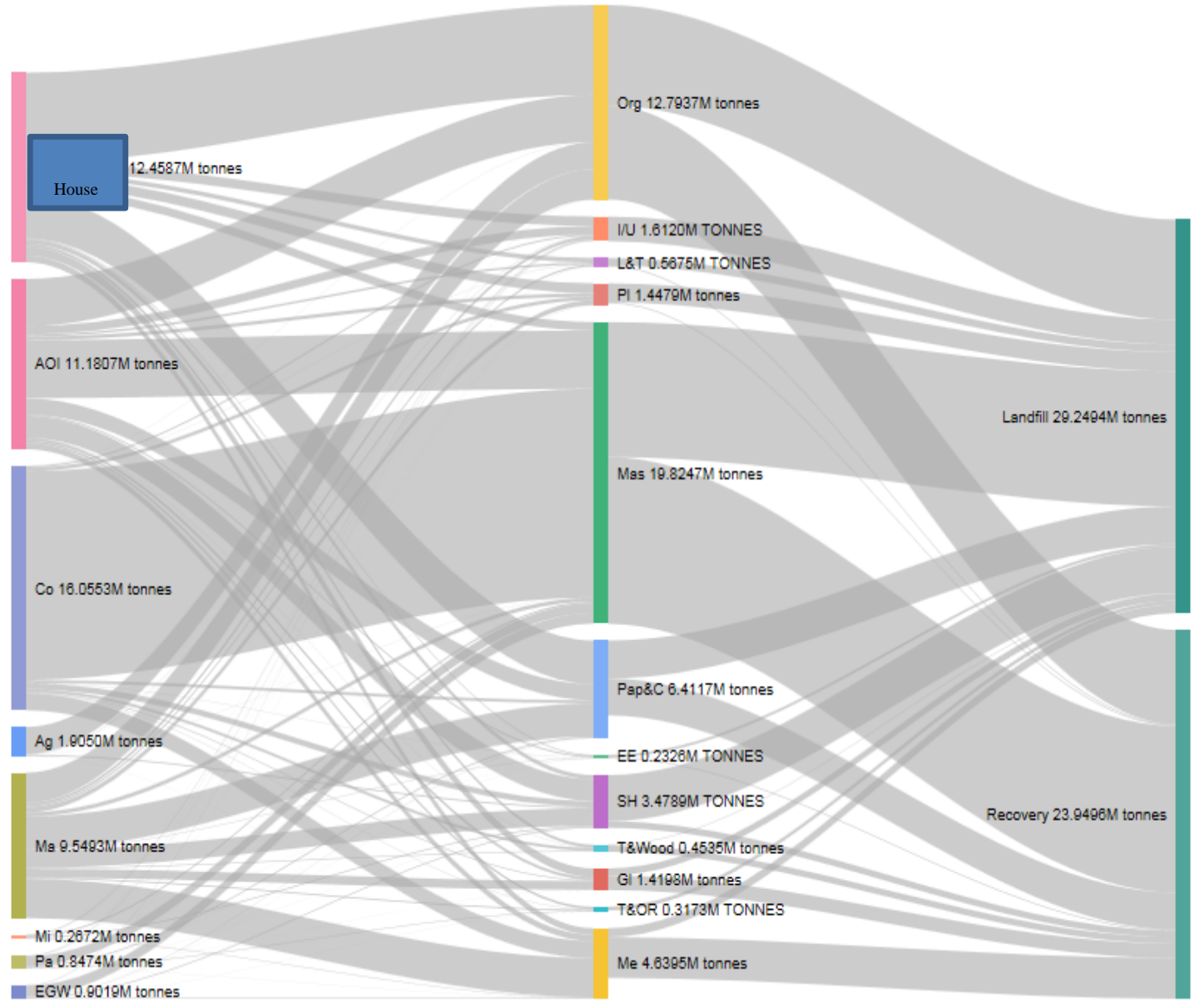

Figure 7. Physical flow of waste footprints in the Australian WIO table in 2009-2010; waste generated by intermediate sectors (left) and the households (left), sorted into 12 categories (middle), and dealt with by two waste treatment methods (right). Final demand refers to the households. Agriculture, forestry, and fishing = AG; Mining = MI; Manufacturing = MA; Electricity, gas, and water = EGW; Waste management services $=$ WMS; Construction $=$ CO; Public administration $=$ PA; All other industry $=$ AOI.

Figure 8 indicates that the Construction sector still generated the largest amount of waste in 2010-2011, although the tonnage was reduced when compared to the amount generated in 2009-2010. Waste generated by the Household sector increased to 14.2686 M tonnes from 2009-2010 to 2010-2011, 
which is slightly lower than that generated by the Construction sector (14.4911 M tonnes) in 2010-2011. The Mining sector generated the lowest amount of waste, growing from $0.2672 \mathrm{M}$ tonnes in 2009-2010 to $0.6059 \mathrm{M}$ tonnes in 2010-2011.

The masonry waste is the largest waste category, which decreased from $19.8247 \mathrm{M}$ tonnes in 2009-2010 to $16.2580 \mathrm{M}$ tonnes in 2010-2011, while the amount of the EE waste was the lowest, growing slightly from $0.2326 \mathrm{M}$ tonnes in 2009-2010 to $0.2377 \mathrm{M}$ tonnes in 2010-2011. The amount of PL, Org, T \& Wood, and I/U waste increased during the period. In particular, the amount of T \& Wood increased by a four-fold rate, from $0.4535 \mathrm{M}$ tonnes in 2009-2010 to 2.0047 M tonnes in 2010-2011 (see Figures 7 and 8).

The waste intensity of intermediate sectors and the Household sector depicts the number of per tonnes of waste generation per million \$AUD in intermediate sectors and the Household sector in 2009-2010 and 2010-2011 (see Figure 9). The three intermediate sectors with the highest waste intensity were the Construction sector, the Agriculture, forestry, and fishing sector, and the Manufacturing sector, while the Mining sector generated the lowest number of waste intensity during the period.

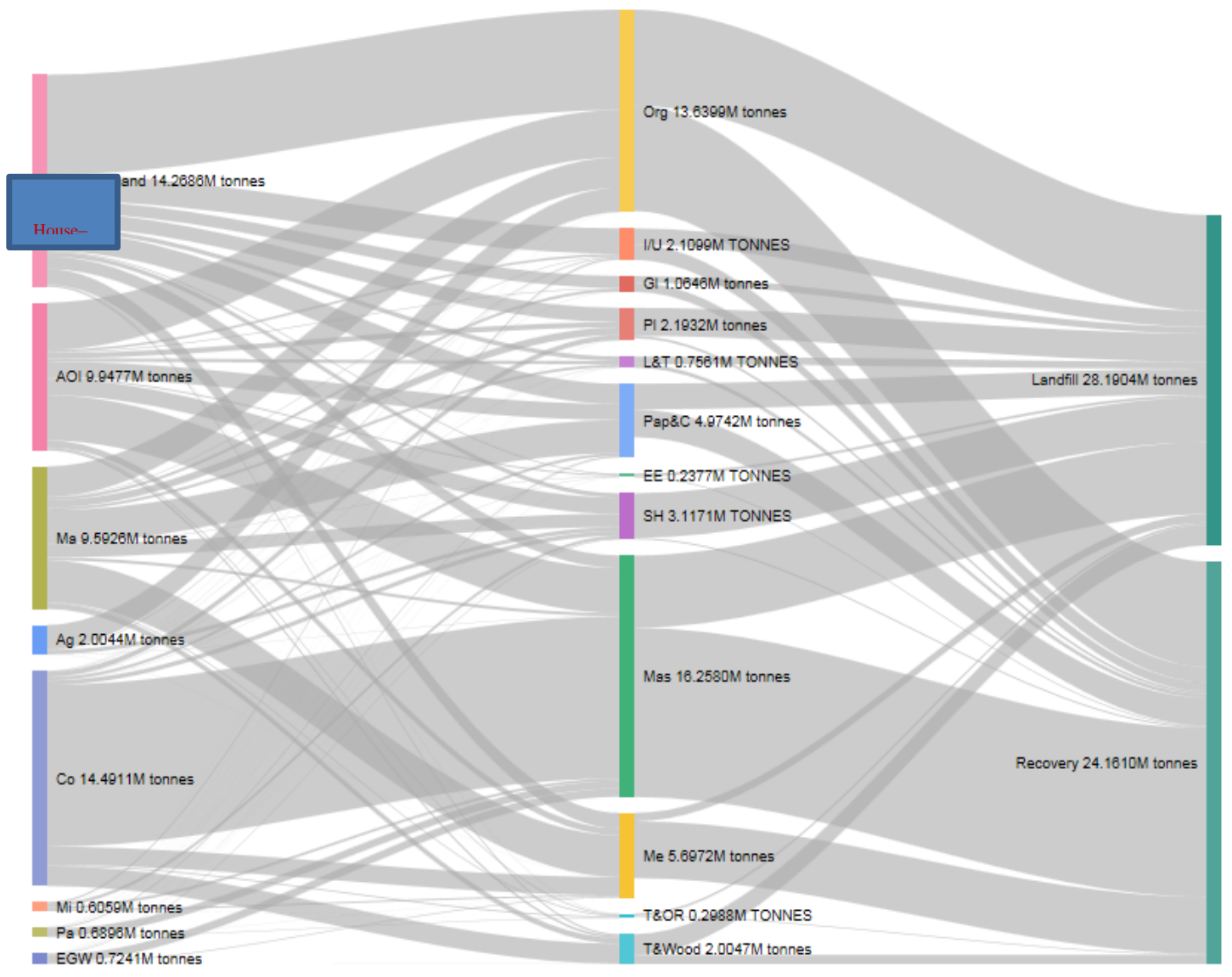

Figure 8. Physical flow of waste footprints in the Australian waste input output (WIO) table of 2010-2011; waste generated by intermediate sectors (left) and the households (left), sorted into 12 categories (middle), and dealt with by two waste treatment methods (right). Final demand refers to the households. Agriculture, forestry, and fishing = AG; Mining = MI; Manufacturing = MA; Electricity, gas, and water $=$ EGW; Waste management services $=$ WMS; Construction $=\mathrm{CO}$; Public administration = PA; All other industry $=$ AOI. 


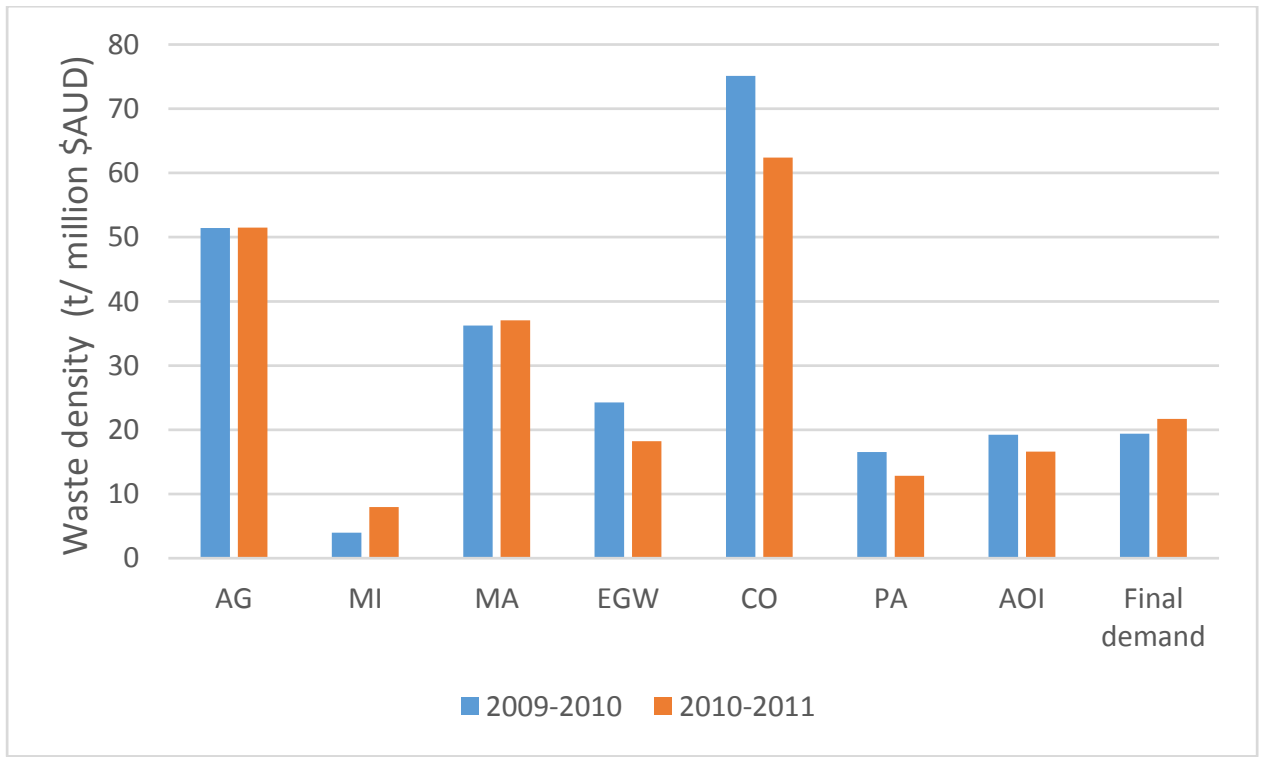

Figure 9. The waste generation intensity in intermediate sectors and the households in 2009-2010 and 2010-2011, within the Australian economy. Agriculture, forestry, and fishing = AG; Mining = MI; Manufacturing = MA; Electricity, gas, and water = EGW; Waste management services = WMS; Construction $=\mathrm{CO} ;$ Public administration $=\mathrm{PA} ;$ All other industry $=$ AOI .

\section{Discussion}

The aim of this article was to analyse the relationships between the Australian economy and waste generation and treatment. A comparative analysis of the Australian WIO tables of 2009-2010 and 2010-2011 has been conducted to illustrate the relationships. Finally, the physical flows of the waste footprints in these two years have shown the origins and destinations of waste generated in the Australian economy.

The paper formed complete time-series Australian IOTs by interpolating and extrapolating the missing Australian IOT in 2010-2011. The data of the Australian aggregation IOT in 2010-2011 were interpolated and extrapolated by linear polynomial and quadratic polynomial based on time-series data of the Australian national economic accounts. The comparative analysis of interpolation and extrapolation shows that the forecasting results of interpolation are more accurate than those of extrapolation because the process of interpolation accesses to more future and effective data than that of extrapolation. This result in the trend of extrapolation is sometimes opposite to the real situation of Australian economy in this context. Therefore, the interpolation of Australian IOT in 2010-2011 has been used to build the Australian WIO model in 2010-2011.

The results of this study showed some special features of the effects of Australian economic activities on waste generation and treatment during the two years. The first finding was that per million \$AUD of output of the Construction sector generated the largest amount of direct and total waste in 2009-2010 and 2010-2011, compared with the results of C. J. Reynolds et al. (2014) [12], who observed that the Service (notably construction) industry generated the largest amount of direct and total waste in 2008, and Fry et al. (2015) [13] who showed that the Construction sector produced the largest amount of waste in 2011-2012. Second, when the inputs from intermediate sectors on some intermediate sector increase during the period, the amount of waste generated by this sector also increases, and vice versa. This relationship illustrates that the Australian economy is a traditional linear economy now. Therefore, the National Waste Policy and the Environment Protection Regulations 2009 are necessary for Australia to recycle resources and promote greater resource productivity aiming to reduce less waste. These policies assist the transition of the Australian economy from a traditional linear economy to a circular economy. Third, the decrease in the sums of direct and total effects of 
intermediate sectors on the Landfill and Recovery sector is a positive indicator for Australian waste management system. It refers to the effectiveness of waste-related policies $[5,6]$ on waste management. However, the information that the sums of direct and total effects on the Landfill sector is more than that on the Recovery sector indicates that the Landfill sector currently plays a more important role than the Recovery sector in Australian waste treatment. This means the decision-makers should pay more attention to policies that generate less waste to the Landfill sector and encourage the development of the Recovery sector.

Finally, the amount of waste generated by the Household sector increased sharply during the two years. This increase of the amount of waste generated by the Household sector can be explained by the growing of final consumption expenditures of households, from 180,074 million \$AUD in June 2010 to 186,009 million \$AUD in June 2011 [24], and the rise of the population from 22.3 million to 22.5 million in the two years $[25,26]$.

In light of the major findings mentioned above, the importance of these results is discussed. First, the comparative analysis of the differences of direct and total effects from intermediate sectors on intermediate sectors and waste generation show how the development of Australian economic elements has effects on waste generation during the period. This method can be applied into the System of Environmental-Economic Accounting due to the publication of the unifying framework for waste generation accounts and national economic accounts to analyse these effects. Then, the direct and total effects from intermediate sectors on intermediate sectors and waste treatment indicate that the comparative analysis of the Australian WIO model is an effective method to assess environmental policies that aim to decrease waste generation. Finally, according to the sharp rise of the amount of the waste generated by the Household sector in these two years, it can be concluded that household waste will be one of the main sources of waste, and more policies and funds should focus on the treatment of household waste.

While the comparative analysis of the Australian WIO model has been used to effectively analyse the relationships between the Australian economy and waste generation and treatment, the method includes two limitations. First, the interpolation and extrapolation of the Australian IO table of 2010-2011 contains uncertainty. For this study, a series of Australian IOTs to estimate an Australian IOT of 2010-2011 was applied. The process of estimation includes proxy information. Additionally, the approach used for the proportionality assumption also contains uncertainty. The research applies the weight of the amount of waste treated by the Landfill sector and the Recovery sector to disaggregate the column of the monetary flow of the Waste management services into two columns of the monetary flow of the Landfill sector and the Recovery sector. The allocation error of the proportionality assumption leads to the inaccuracy of the formation of the Australian WIO model.

\section{Conclusions}

The methodology showed in this paper employs a hybrid analysis by combining WIO analysis with interpolation, thus vastly expanding the application with consistent and comparable effects of Australian economic activities on waste management. The consistent analysis of the aggregation of WIO by intermediate sectors, the households and the data of waste generation and treatment, embodies the following deliverables:

- The interpolation procedure builds time-series WIO tables with standardised economic and waste national accounts, which enables the analysis of relationships between the changes of economic system and waste generation to be realistic. As illustrated in Figures 6 and 7, the growth of waste generation can be strongly related to the growth of the input in an intermediate sector (such as the Mining sector), and vice versa.

- As shown in Tables 12 and 13, the sum of direct and total effects of intermediate sectors on the Landfill sector decreased by 0.0094 and 0.0201 . The result is particularly important for assessing the effectiveness of published Australian environmental policies. 
- The largest amount of waste generated by the Construction sector was $16.06 \mathrm{M}$ tonnes in 2009-2010 and dropped to $14.49 \mathrm{M}$ tonnes in 2010-2011. The result indicates that it is necessary for the Australian waste management system to concentrate on the construction waste.

- Physical flow of waste footprints enumerates the full supply-chain waste generation and treatment for the Australian economy. For example, almost $69 \%$ of the Masonry waste is generated by the Construction sector, and more than 50\% of the Masonry waste is landfilled in 2009-2010.

Furthermore, the results of this article point out a future direction for the WIO analysis. The analysis in the paper only discusses the effects of intermediate sectors on waste generation, and there is no discussion to explain the effects of the households, in which the amount of waste increased sharply in two years. Proper consideration of the effect of the Household sector is of great significance for the amount of waste, because households are an endogenous factor for waste generation, i.e., that the levels of household income determine the levels of people's consumption, and therefore influence the amount of waste generation. In this case, bringing the Household sector into intermediate sectors will be a significant step to build a closed WIO model.

Supplementary Materials: The following are available online at www.mdpi.com/2313-4321/2/3/12/s1.

Acknowledgments: The authors received financial support from the Cooperative Research Centre (CRC) for Low Carbon Living Project RP2002: Integrated Energy, Transport, Water and Waste (ETWW) Demand Forecasting. The authors would like to thank Malgorzata Korolkiewicz, Atiq Zaman, and Nicholas Holyoak for their helpful comments and suggestions.

Author Contributions: H.H., J.P., and J.B. conceived and designed the experiments; H.H. performed the experiments; H.H., C.J.R., and J.B. analyzed the data; H.H. and J.B. contributed reagents/materials/analysis tools; H.H. and C.J.R. wrote the paper.

Conflicts of Interest: The authors declare no conflict of interest.

\section{References}

1. Shekdar, A.V. Sustainable solid waste management: An integrated approach for Asian countries. Waste Manag. 2009, 29, 1438-1448. [CrossRef] [PubMed]

2. Daskalopoulos, E.; Badr, O.; Probert, S. Municipal solid waste: A prediction methodology for the generation rate and composition in the European Union countries and the United States of America. Resour. Conserv. Recycl. 1998, 24, 155-166. [CrossRef]

3. Hoornweg, D.; Bhada-Tata, P.; Kennedy, C. Peak waste: When is it likely to occur? J. Ind. Ecol. 2015, 19, 117-128. [CrossRef]

4. Australian Bureau of Statistics (ABS). 4602.055.0052013a Waste Account, Australia, Experimental Estimates, 2013; Australian Bureau of Statistics: Canberra, Australia, 2013. Available online: http:/ / www.abs.gov.au/ausstats/abs@.nsf/Latestproducts/4602.0.55.005Main\%20Features42013? opendocument\&tabname=Summary\&prodno=4602.0.55.005\&issue=2013\&num $=\& v i e w=\backslash$ T1 $\backslash$ textgreater \{\} (accessed on 13 April 2016).

5. Australian Government Department of the Environment and Energy. National Waste Policy Implementation Report 2012 and 2013; Department of the Environment and Energy: Canberra, Australia, 2014. Available online: http:/ / www.environment.gov.au/protection/national-waste-policy/publications/implementationreport-2012-and-2013 (accessed on 18 May 2016).

6. The Environment Protection Authority. Penalties for Late Lodgment and/or Payment of Environmental Authorization Fees and Waste Levies; The Environment Protection Authority: Canberra, Australia, 2015. Available online: http://www.epa.sa.gov.au/business_and_industry/licences/penalties (accessed on 18 May 2016).

7. Miller, R.E.; Blair, P.D. Input-Output Analysis: Foundations and Extensions; Cambridge University Press: Cambridge, UK, 2009. 
8. Leontief, W. Environmental repercussions and the economic structure: An input-output approach. Rev. Econ. Stat. 1970, 52, 262-271. [CrossRef]

9. Nakamura, S.; Kondo, Y. Input-output analysis of waste management. J. Ind. Ecol. 2002, 6, 39-63. [CrossRef]

10. Joosten, L.; Hekkert, M.P.; Worrell, E. Assessment of the plastic flows in the Netherlands using STREAMS. Resour. Conserv. Recycl. 2000, 30, 135-161. [CrossRef]

11. Nakamura, S.; Kondo, Y. Recycling, landfill consumption, and $\mathrm{CO}_{2}$ emission: Analysis by waste input-output model. J. Mater. Cycles Waste Manag. 2002, 4, 2-11.

12. Reynolds, C.J.; Piantadosi, J.; Boland, J. A waste supply-use analysis of Australian waste flows. J. Econ. Struct. 2014, 3, 1-16. [CrossRef]

13. Fry, J.; Lenzen, M.; Giurco, D.; Pauliuk, S. An Australian Multi-Regional Waste Supply-Use Framework. J. Ind. Ecol. 2015, 20, 1295-1305. [CrossRef]

14. UN; European Union; Food and Agriculture Organization; International Monetary Fund; Organisation for Economic Co-operation and Development; The World Bank. The System of Environmental-Economic Accounting (SEEA) Central Framework; United Nations Publications: New York, NY, USA, 2014.

15. Reynolds, C.; Geschke, A.; Piantadosi, J.; Boland, J. Estimating industrial solid waste and municipal solid waste data at high resolution using economic accounts: An input-output approach with australian case study. J. Mater. Cycles Waste Manag. 2015, 18, 677-686. [CrossRef]

16. Australian Bureau of Statistics (ABS). 46550DO001_2016 Australian Environmental-Economic Accounts, 2016; Australian Bureau of Statistics: Canberra, Australia, 2016. Available online: http://www.abs.gov.au/ AUSSTATS/abs@.nsf/DetailsPage/4655.02016?OpenDocument (accessed on 21 May 2016).

17. Australian Bureau of Statistics (ABS). 4602.0.55.006 - Waste Account, Australia, 2010-11; Australian Bureau of Statistics: Canberra, Australia, 2014. Available online: http:/ / www.abs.gov.au/Ausstats/abs@.nsf/0/ 682A9D1590A1168DCA257CCA00194E7E?OpenDocument (accessed on 08 April 2016).

18. Australian Bureau of Statistics (ABS). 5209.0.55.001-Australian National Accounts: Input-Output Tables-Electronic Publication, Final Release 2006-07 Tables; Australian Bureau of Statistics: Canberra, Australia, 2010. Available online: http:/ / www.abs.gov.au/AUSSTATS/abs@.nsf/allprimarymainfeatures/ 2712A50C1AED7AC9CA2579180012FCA5?opendocument (accessed on 19 Feburary 2016).

19. Australian Bureau of Statistics (ABS). 5209.0.55.001-Australian National Accounts: Input-Output Tables-Electronic Publication, 2007-08 Final; Australian Bureau of Statistics: Canberra, Australia, 2011. Available online: http://www.abs.gov.au/AUSSTATS/abs@.nsf/allprimarymainfeatures/ 974E5830633EACB9CA257A720011A0FB?opendocument (accessed on 19 February 2016).

20. Australian Bureau of Statistics (ABS). 5209.0.55.001-Australian National Accounts: Input-Output Tables, 2008-09; Australian Bureau of Statistics: Canberra, Australia, 2012. Available online: http://www. abs.gov.au/AUSSTATS/abs@.nsf/allprimarymainfeatures/865EB70D488187DDCA257BEB00112BAA? opendocument (accessed on 19 Feburary 2016).

21. Australian Bureau of Statistics (ABS). 5209.0.55.001-Australian National Accounts: Input-Output Tables, 2009-10; Australian Bureau of Statistics: Canberra, Australia, 2013. Available online: http://www. abs.gov.au/AUSSTATS/abs@.nsf/allprimarymainfeatures/738D25E1A23B4FF4CA257E6E0011AD13? opendocument (accessed on 10 April 2016).

22. Australian Bureau of Statistics (ABS). 5209.0.55.001-Australian National Accounts: Input-Output Tables, 2012-13; Australian Bureau of Statistics: Canberra, Australia, 2015. Available online: http:/ /www.abs.gov. au/AUSSTATS/abs@.nsf/DetailsPage/5209.0.55.0012012-13?OpenDocument (accessed on 01 April 2016).

23. Australian Bureau of Statistics (ABS). Australian and New Zealand Standard Industrial Classification (ANZSIC), 2006; Australian Bureau of Statistics: Canberra, Australia, 2008; Volume 4. Available online: http:/ /www. abs.gov.au/ausstats/abs@.nsf/PrimaryMainFeatures/1292.0?OpenDocument (accessed on 10 March 2016).

24. Australian Bureau of Statistics (ABS). 5206.0-Australian National Accounts: National Income, Expenditure and Product, Mar 2016; Australian Bureau of Statistics: Canberra, Australia, 2016. Available online: http:/ / www.abs.gov.au/AUSSTATS/abs@.nsf/DetailsPage/5206.0Mar\%202016?OpenDocument (accessed on 23 May 2016). 
25. Australian Bureau of Statistics (ABS). 3101.0-Australian Demographic Statistics, Dec. 2011; Australian Bureau of Statistics: Canberra, Australia, 2012. Available online: http://www.abs.gov.au/ausstats/abs@.nsf/ lookup/3101.0Media\%20Release1Dec\%202011 (accessed on 16 June 2016).

26. Australian Bureau of Statistics (ABS). 1370.0.55.001-Measures of Australia's Progress: Summary Indicators, 2011; Australian Bureau of Statistics: Canberra, Australia, 2011. Available online: http:/ /www.abs.gov.au/ ausstats/abs@.nsf/Lookup/by\%20Subject/1370.0.55.001 2011 Main\%20Features Population 3 (accessed on 16 Feburary 16).

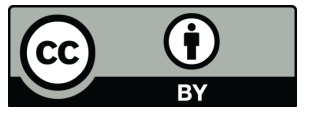

(C) 2017 by the authors. Licensee MDPI, Basel, Switzerland. This article is an open access article distributed under the terms and conditions of the Creative Commons Attribution (CC BY) license (http://creativecommons.org/licenses/by/4.0/). 